\title{
Ecosystem services from a degraded peatland of Central Kalimantan: implications for policy, planning, and management
}

\author{
Elizabeth A. Law, ${ }^{1,6}$ Brett A. Bryan, ${ }^{2}$ Erik Meijaard, ${ }^{1,3}$ Thilak Mallawaarachchi, ${ }^{4}$ Matthew Struebig, ${ }^{5}$ \\ AND KERRIE A. WILSON ${ }^{1}$ \\ ${ }^{1}$ University of Queensland, School of Biological Sciences, Brisbane, Queensland 4072 Australia \\ ${ }^{2}$ CSIRO Land and Water Flagship, Waite Campus, Gate 4 Waite Road, Urrbrae, \\ South Australia 5064 Australia \\ ${ }^{3}$ Borneo Futures Project, People and Nature Consulting International, Country Woods House 306, JL, WR Supratman, \\ Pondok Ranji-Rengas, Ciputat, Jakarta, Indonesia \\ ${ }^{4}$ University of Queensland, Risk and Sustainable Management Group, Brisbane, Queensland 4072 Australia \\ ${ }^{5}$ Durrell Institute of Conservation and Ecology, School of Anthropology and Conservation, University of Kent, Canterbury, \\ Kent CT2 7 NZ United Kingdom
}

\begin{abstract}
Increasingly, landscapes are managed for multiple objectives to balance social, economic, and environmental goals. The Ex-Mega Rice Project (EMRP) peatland in Central Kalimantan, Indonesia provides a timely example with globally significant development, carbon, and biodiversity concerns. To inform future policy, planning, and management in the EMRP, we quantified and mapped ecosystem service values, assessed their spatial interactions, and evaluated the potential provision of ecosystem services under future land-use scenarios. We focus on key policy-relevant regulating (carbon stocks and the potential for emissions reduction), provisioning (timber, crops from smallholder agriculture, palm oil), and supporting (biodiversity) services. We found that implementation of existing land-use plans has the potential to improve total ecosystem service provision. We identify a number of significant inefficiencies, trade-offs, and unintended outcomes that may arise. For example, the potential development of existing palm oil concessions over one-third of the region may shift smallholder agriculture into low-productivity regions and substantially impact carbon and biodiversity outcomes. While improved management of conservation zones may enhance the protection of carbon stocks, not all biodiversity features will be represented, and there will be a reduction in timber harvesting and agricultural production. This study highlights how ecosystem service analyses can be structured to better inform policy, planning, and management in globally significant but data-poor regions.
\end{abstract}

Key words: biodiversity; carbon; deforestation; ecosystem services; Kalimantan; land-use change; palm oil; peatland; REDD+; spatial planning.

\section{INTRODUCTION}

Land-use allocation and management is a complex task that involves balancing multiple objectives (Nassauer and Opdam 2008, Reyers et al. 2012). Demand for agriculture increases pressure to develop land, while global calls for sustainability (Nelson et al. 2009, Koh and Ghazoul 2010) necessitate consideration of the services provided by ecosystems as an essential component of land-use planning (CBD 2003, Millennium Ecosystem Assessment 2005). There is also growing recognition of the need to build resilience and adaptive capacity (Lambin et al. 2003, Folke et al. 2004, Game et al. 2008). With a variety of values derived from landscapes, determining socially, ecologically, and economically desirable land-use allocations is challenging (Mallawaarachchi and Quiggin 2001),

Manuscript received 1 November 2013; revised 1 April 2014; accepted 11 June 2014. Corresponding Editor: S. P. Faulkner

6E-mail: e.law@uq.edu.au and trade-offs between objectives are likely (Rodriguez et al. 2006, Nelson et al. 2009, Koh and Ghazoul 2010, Bryan and Crossman 2013). Recent technical advancements in land-use planning and ecosystem service assessments have included ways to explicitly account for multiple uses, stakeholders, and benefits (Klein et al. 2008, Bryan et al. 2010, Wilson et al. 2010, Willemen et al. 2012), explore trade-offs between competing uses (Naidoo and Ricketts 2006, Laterraa et al. 2012, Venter et al. 2012), and account for interactions between social, economic, and ecological sectors (Busch et al. 2012, Bryan and Crossman 2013, Ruijs et al. 2013). These assessments are essential to inform policy, planning, and management in places such as the ExMega Rice Project area (EMRP; Fig. 1) of Central Kalimantan, Indonesian Borneo; a region with globally significant development, carbon, and biodiversity challenges.

The EMRP region is the result of an agricultural selfsufficiency and development policy implemented during 1996-1998 that cleared almost one million hectares of 


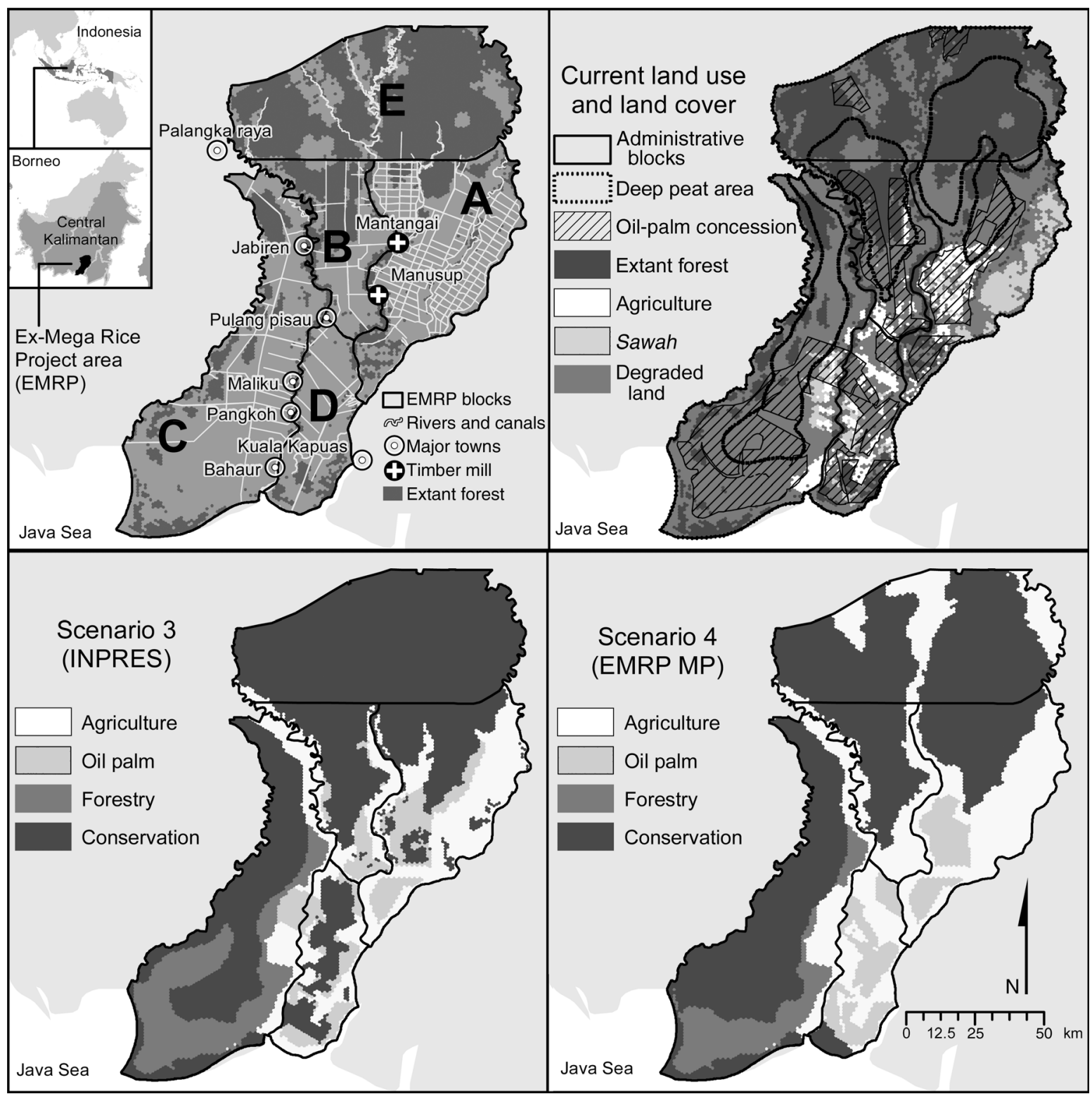

FIG. 1. Location of the study region in Central Kalimantan, Indonesia, administrative blocks, current land use and land cover, and distribution of zones under scenario 3 (development as per the zoning plan outlined in Presidential Instruction No. 2/2007 on rehabilitation and revitalization of the Ex-Mega Rice Project Area in Central Kalimantan; INPRES) and scenario 4 (development as per the zoning plan outlined in the EMRP "master plan" project; EMRP MP). Sawah systems are seasonally irrigated agricultural fields.

tropical lowland peat swamp forest (see Plate 1) and created $4000 \mathrm{~km}$ of canals for drainage and irrigation in Central Kalimantan (Page et al. 2009). The project failed to achieve its agricultural objectives, and subsequent abandonment of agricultural lands and ongoing degradation in the area has led to negative consequences for hydrology and greenhouse gas (GHG) emissions. Without disturbance, peatland carbon stocks are generally stable (Page et al. 2002). Drainage causes an irreversible process of drying, oxidation, and collapse (Wosten et al. 2008). This increases peat susceptibility to fire (Hooijer et al. 2006), which releases significant amounts of $\mathrm{CO}_{2}$ to the atmosphere (Page et al. 2002), particularly in extreme El Niño years (Page et al. 2002, Ballhorn et al. 2009, Hooijer et al. 2010). Widespread peat fires in the 1997 El Niño year attracted considerable international attention due to both large-scale health impacts (Aditama 2000) and GHG emissions (Page et al. 2002, PEACE 2007). Drained peatlands account for between $6 \%$ and $8 \%\left(2.0 \times 10^{9} \mathrm{Mg} \mathrm{CO}_{2} \mathrm{e} / \mathrm{yr}\right.$ [carbon dioxide equivalent/yr]) of global GHG emissions, most (90\%) of which come from Indonesia (Hooijer et al. 
2006). Emissions from peatland account for $\sim 60 \%$ of Indonesia's total emissions (Joosten et al. 2012).

In addition to these carbon and hydrological impacts, the ability of peatlands to support biodiversity (Morrogh-Bernard et al. 2003, Posa 2011, Posa et al. 2011) and livelihoods for local communities (Silvius and Suryadiputra 2004) has been severely degraded in the EMRP. Land clearance, logging (both legal and illegal), and agricultural land management have severely affected populations of endangered endemic species such as the Bornean orangutan (Pongo pygmaeus; see Plate 1; Meijaard 1997, Wich et al. 2012), and greatly reduced the capacity to support mature or regenerating forests (Page et al. 2009). Many families translocated from outside Kalimantan during the attempted agricultural development phase remain in the EMRP area, and are affected by poor agricultural yields and high poverty rates. In 2005 , poverty reached $36 \%$ across the region, and in some transmigrant villages poverty rates were as high as $75 \%$ (de Groot 2008). These rates compare poorly with overall poverty levels in the province $(9.4 \%$ in 2007; Bidang Statistik Sosial 2012). Local communities in the region draw their income predominantly from small-scale agriculture (average 2.5-ha plots; van den Berg and Widiadi 2008), partly supplemented by offfarm activities including construction and illegal forestry (Böhm and Siegert 2004).

The policy problem for the EMRP region is the suboptimal provision of ecosystem services, where there are many free riders of resource use leading to local, regional, and global inefficiencies. This problem is characterized by a lack of understanding of the nature of trade-offs associated with different land-use options and how resources might be optimally used in the region. Maps of ecosystem service values can provide tools for communication and stakeholder engagement in the initial stages of land-use policy development and implementation (Burkhard et al. 2013, Maes et al. 2013), but such information is not available for this region. Ecosystem service maps are also a crucial input into analyses aimed at determining the most efficient use of resources and the benefits, risks, and trade-offs associated with land-use management options (Chan et al. 2006, O'Farrell et al. 2010, Busch et al. 2012, Bryan 2013, Ruijs et al. 2013).

We quantify the spatial distribution of ecosystem service values at a regional scale to understand the tradeoffs and synergies associated with productive (consumptive) land uses and conservation. We focus on determining potential future supply of services under a range of land-use and management regimes including forestry, smallholder agriculture, oil-palm development, forest restoration, and conservation. We develop a spatially and temporally explicit process-based model for estimating carbon emissions that accounts for the impact of fire; quantify the economic profit from smallholder farming systems; and develop a metric of biodiversity importance based on representation and complementar- ity. In the first ecosystem service maps constructed for this globally important region, we assess ecosystem service patterns and potential trade-offs, and evaluate the performance of four land-use scenarios in terms of the potential future supply of ecosystem services.

\section{Methods}

We used an integrated spatial modeling and assessment methodology to quantify, map, and value multiple ecosystem services for the EMRP study area (Table 1). For the entire study area, we modeled and mapped the potential supply of provisioning services (timber from forestry, crops from smallholder agriculture, and oil from palm plantations), and biodiversity conservation from ecological restoration of cleared areas and the conservation management of natural areas. Regulating services (i.e., carbon emissions) were calculated for all land uses (i.e., forestry, smallholder agriculture, oil palm, conservation, and no active management). We classify ecosystem services used in this study following the Millennium Ecosystem Assessment (2005), but acknowledge the limitations of this framework and the ongoing effort to refine definitions, particularly to distinguish between ecosystem services and other benefits (e.g., Fisher et al. 2009). Consideration of provisioning services, such as those derived from agricultural land use, is particularly ambiguous. Here, we quantify ecosystem services based on the potential value of benefits derived over the planning horizon. We do not distinguish between contributions of ecological, human, and built capital in the production of these benefits, but note that all services we evaluate do require additional forms of capital to be developed, and all land uses (including unmanaged) are a result of specific management decisions and actions.

Where monetary values are used, these are given in 2008 US\$. We used commercial discount rates $(10 \%$ per annum; Fisher et al. 2011, Venter et al. 2012). The planning horizon was 40 years (unless otherwise specified), to reflect timber rotations and allow for stabilization of carbon emission projections, while remaining appropriate for standard discounting techniques. Data processing was conducted in $\mathrm{R}$ (version 2.15.2; R Core Team 2012), including contributed packages raster (version 2.0-31; Hijmans and van Etten 2012), tree (version 1.0-33; Ripley 2012), lme4 (version 0.9-0; Bates et al. 2012), SpatialPack (version 0.2; Osorio et al. 2012), ArcGIS (version 10; ESRI 2011), and other software as specified. All ecosystem service spatial layers were summarized to the resolution of a 100-ha hexagonal grid cell layer.

\section{Spatial mapping and valuation}

Current land use and land cover.-The EMRP region currently consists of a combination of four broad categories of land use and land cover: extant forest on drained and undrained peat and mineral soils; productive agricultural land under rice and tree crop farming 
systems; sawah systems (seasonally irrigated agricultural fields); and degraded areas, mainly on drained soils, including abandoned agricultural land (Fig. 1; Appendix A). The potential distribution of forest types was required as an input into mapping the potential for emissions reduction and for calculating potential timber value. We classified extant forest into five types (mangrove, swamp forest, riverine-riparian, mixed swamp, and low pole) and used maximum entropy species distribution modeling to map their potential distributions (Phillips 2004, Phillips et al. 2006; Appendix A). Peat depth across the region was determined from a $50 \times 50 \mathrm{~m}$ grid layer developed from the interpolation of approximately 3000 depth cores (Hooijer et al. 2006, Giesen 2008), and areas with a depth greater than $3 \mathrm{~m}$ were identified (Fig. 1).

Carbon.-We modeled both carbon stocks and the potential for emissions reduction (Table 1; Appendix B). Extant carbon stocks are commonly used as a basis for ecosystem service analysis (e.g., Chan et al. 2006, Anderson et al. 2009, Eigenbrod et al. 2010). Carbon stocks in aboveground biomass, belowground biomass, and dead wood (necromass) were allocated using a landcover proxy, while soil carbon stocks were estimated based on soil type and depth of peat (Appendix B).

In order to estimate emissions reduction, we developed a novel process-based model, as a standard stockdifference approach would not have adequately captured important carbon flux dynamics (Murdiyarso et al. 2010). Five types of carbon flux were defined: (1) peat oxidation in the absence of fire, (2) vegetation sequestration in the absence of fire, (3) carbon loss from peat due to fire events, (4) carbon loss from vegetation due to fire events, and (5) carbon temporarily stored in harvested wood products (HWP) (Law et al. in press).

Carbon flux was simulated at yearly intervals. Each year, either a fire or harvest occurred and carbon was lost due to combustion of biomass and peat, or temporarily stored in HWP, or a fire/harvest did not occur and carbon was sequestered in plant growth, and lost through peat oxidation (Appendix B). The probability of fire was modeled using a generalized linear hierarchical mixed-effects regression model (version 0.90; Bates et al. 2012) informed by MODIS hotspot data for the years 2000-2006, which included one major El Niño event. The potential for emissions reduction was estimated by comparing expected emissions from maintaining current land management to that from smallholder agriculture, oil palm, forestry, no management (uncontrolled and stochastic fire events), or conservation (complete fire control, and the regeneration, restoration, and/or management of forest).

Timber.-Forestry is a viable land management option with potential to rehabilitate forest and peat and support economic development (van der Meer and Ibie 2008). Illegal logging is known to occur in the eastern and western portions of block $\mathrm{E}$ and the northern portion of block B (Fig. 1), targeting commercially important species such as ramin (Gonystylus bancanus), meranti (Shorea spp.), jelutung (Dyera polyphylla; latex), and terentang (Campnosperma coriaceum) (van der Meer and Ibie 2008).

We estimated the potential value of harvesting timber from the commercially viable riverine-riparian and mixed-swamp forest types. This was calculated as the net present value (NPV, US\$ per ha) over the first cutting cycle (40 years) under a conventional harvest volume $\left(65 \mathrm{~m}^{3} / \mathrm{ha}\right.$; Ruslandi and Putz 2011). Harvest years were designated as year zero for extant forest (cover $>10 \%$ ), year 20 for currently degraded forest (woody vegetation types as identified by the current land-use layer, with less than $10 \%$ cover), and year 40 for currently cleared areas predicted to support mixedswamp and riverine-riparian forest regrowth. NPV was calculated as the sum of net returns discounted over time given the potential yield, a standard log price $\left(\$ 122 / \mathrm{m}^{3}\right)$, harvest costs $\left(\$ 59 / \mathrm{m}^{3}\right.$; Ruslandi and Putz 2011), and transport costs (minimum by road or river; Appendix C; Table 1).

Smallholder agriculture.-Typically in ecosystem service assessments only one crop is valued, or else the value of multiple crops is considered separately (Crossman et al. 2013). We developed a novel method to map and value smallholder farming systems in the EMRP to reflect the cultural preference for holdings to include a range of subsistence and cash crops. We categorized smallholder farming systems as rice, coconut, rubber, and rubber mosaic. These farming systems were defined according to the dominant crop but consisted of varying proportions of rice, rubber, coconut, maize, soy, and horticulture. Suitability maps were available for each crop except coconut across the major agricultural areas (62\% of the total study region, covering blocks A, B, and D; Giesen 2008). To map farming systems, we simplified the original categorical crop suitability scores into five categories: $0 \%, 25 \%, 50 \%, 75 \%$, and $100 \%$ of the maximum potential yield for each crop. We determined the likelihood of each cell being in each yield category using classification tree models (Ripley 2012; Appendix D), as predicted by the explanatory variables of hydrology, physiography, annual mean temperature, peat depth, and distance from major rivers. Misclassification rates were between 18\% and 35\% (Appendix D).

To obtain an estimate of the potential value of smallholder agriculture, we calculated the expected net economic returns of each farming system for each cell by weighting the expected net revenue for each crop (accounting for the likelihood of each cell being in each yield category) by its contribution to each farming system (Table 1 and Appendix D: Tables D2-D4). The expected revenues for smallholder agriculture were estimated as "farm-gate" values as farmers generally sell directly into local markets. Farm-gate is defined by the OECD as the price of the product available at the farm, excluding any separately billed transport or delivery charges (OECD 2005). Maximum gross reve- 
TABLE 1. Summary of methods and data sources for developing ecosystem service layers in the Ex-Mega Rice Project (EMRP) area.

\begin{tabular}{l}
\hline \hline $\begin{array}{l}\text { Ecosystem service and layer } \\
\text { Regulating } \\
\text { Carbon stocks } \\
\text { Land-cover proxy, soil type, and peat depth. }\end{array}$ \\
$\begin{array}{r}\text { Process model including fire combustion, harvested } \\
\text { wood products (HWP), vegetation sequestration, } \\
\text { and peat oxidation over 40 years. }\end{array}$
\end{tabular}

Provisioning

Timber

Crops from smallholder agriculture

Palm oil

Supporting

Biodiversity importance
$\mathrm{NPV}=\sum_{t=0}^{t=40} \frac{Y_{t} \times\left(\mathrm{Pr}_{t}-\mathrm{HC}_{t}-\mathrm{TC}_{t}\right)}{(1+0.1)^{t}}$

Where:

NPV $=$ net present value over 40 years with $10 \%$ discount rate

$Y_{t}=$ potential yield

$\operatorname{Pr}_{t}=\log$ price

$\mathrm{HC}_{t}=$ harvest costs

$\mathrm{TC}_{t}=$ transport cost

$t=$ year the model is being run for $(0-40)$

$\mathrm{EV}_{i}=\max \{\in \mathrm{FS}\} \sum_{c}^{N} \mathrm{FSC}_{c, f} \times E\left(\mathrm{NR}_{c, i}\right)$

Where:

$\mathrm{EV}_{i}=$ annual expected value for each cell; the farming system with the maximum expected revenue

$\mathrm{FSC}_{c, f}=$ contribution of $\operatorname{crop} c(c=1 \ldots N)$ to farming system $f$

$E\left(\mathrm{NR}_{c, i}\right)=$ expected net revenue from crop $c$ in cell $i$ calculated as:

$E\left(\mathrm{NR}_{c, i}\right)=\sum_{y=1}^{y} P_{S, i} S_{y} \mathrm{NR}_{\mathrm{cmax}}$

where:

$P_{S, i}=$ the likelihood cell $i$ is within suitability class $S$

$S_{y}=$ the suitability percentage for yield $y$

$\mathrm{NR}_{\mathrm{cmax}}=$ the net revenue expected from maximum suitability for $\operatorname{crop} c$, calculated as:

$\mathrm{NR}_{\mathrm{c} \max }=\left(Y_{\mathrm{cmax}} \times \operatorname{Pr}_{c}\right)-\frac{\left(Y_{\mathrm{cmax}} \times \mathrm{Pr}_{c}\right)}{\left(\mathrm{RC}_{c}+1\right)}$

where:

$Y_{\mathrm{cmax}}=$ maximum yield of crop $Y$

$\operatorname{Pr}_{c}=$ producer price of crop $c$

$\mathrm{RC}_{c}=$ revenue cost ratio of crop $c$

$\mathrm{NPV}=\sum_{S}^{M} P\left(S_{s}\right) \times \mathrm{NPV}_{s}$

Where:

$\mathrm{NPV}=$ net present value over 25 years (see Appendix E: Table E1)

$P\left(S_{s}\right)=$ likelihood of being in suitability class $s$

$\mathrm{NPV}_{s}=$ net present value for suitability class $s(s=$ 1...M)

Marxan selection frequency, for representation of $30 \%$ of the distribution of each feature
Represents an estimate of current stocks, assumes current land use and land cover.

Calculated the difference from each land management regime and a situation where no fires or agricultural development occur (which is assumed to be optimal for emissions reduction).

This model assumes timber harvesting can potentially occur over the entire region, including where forest must first regenerate, but excluding ineligible forest and land-cover types (i.e., low pole, mangrove, permanently flooded regions, and existing settlements).

This model assumes smallholder agriculture can potentially occur over the entire region, excluding waterbodies and existing settlements.

This model assumes oil palm can potentially occur over the entire region, excluding waterbodies and existing settlements. 
TABle 1. Extended.

Primary data sources

Land-cover proxy for biomass and necromass. Soil-type (Bappeda; regional physical planning program for transmigration) data collated for the EMRP master plan and peat depth from Hooijer et al. (2006), Giesen (2008). All carbon content estimates from literature review.

Initiated with carbon stock data. Probability of fire modeled from MODIS hotspot data. Other parameters, including growth, root/shoot ratio, and biomass burn percentage from literature review. Temporary storage in HWP modeled as a time-discounted value.

Potential yield, harvest regime, log price, and static costs determined by land cover, potential forest type, and informed by literature review. Transport costs modeled as a function of distance from local mills.

Potential yield determined by suitability model developed using classification trees (Appendix D: Table D1). Data on agricultural suitability derived from Puslitanak (soil and agro-climate research centre) data collated for the EMRP management plan in 1996-1997. Yield and prices from FAO (Appendix D: Tables D2-D4). Costs from EMRP master plan and literature review.

Potential suitability modeled using classification trees based on suitability data derived from Puslitanak data collated by the EMRP MP in 1996-1997. NPV for each suitability class from literature review (Appendix E: Table E1).

Maximum entropy species distribution models of nine primates and five forest types using presence records and environmental variables. Distributions represent an estimate of the potential species distribution and the distribution of extant best-quality examples of each forest type. nues were calculated using FAO data on crop values and a revenue cost ratio applied to determine maximum net revenue. Full cost and revenue details are provided in Appendix D. The farming system that gave the highest expected net revenue was allocated to each grid cell.

Palm oil.-As of 2008, oil-palm concessions covered $29 \%$ of the EMRP region (Appendix E: Fig. E1), but only $35 \%$ had been initiated ( $10 \%$ of the region). Of these, the majority had not yet been planted (Appendix E: Fig. E1), and none were mature as of 2008 (Jagau et al. 2008). As for smallholder agriculture, we extrapolated oil-palm suitability scores across the study region using classification tree models (Appendix E) with the explanatory variables of physiography, hydrology, and peat depth. Suitability classes represented areas unsuitable for oil palm, and the first, second, and third quartiles of profits reported from the region (Appendix E: Table E1). We calculated the expected NPV of palm oil from each cell by multiplying the likelihood that each cell is in each suitability class by the net present value for that class (Table 1). We assumed that plantations will be managed by larger commercial operators with the oil processed on-site, and therefore do not account for transport costs.

Biodiversity.-Typically, metrics of species richness or habitat quality are employed in ecosystem service assessments (Willemen et al. 2008, Nelson et al. 2009, Posthumus et al. 2010). We calculated a complementarity-based metric of biodiversity importance of each grid cell for representing nine primate species and five extant forest types (Justus and Sarkar 2002, Chan et al. 2006). In the study region, primates are the most commonly surveyed taxon in biodiversity appraisals, since many primate species are considered to have high conservation value (see Plate 1). However, as the surrogacy value of primates for total biodiversity is inconclusive (Meijaard and Nijman 2003), we also include forest types to represent an ecosystem-level surrogate, and therefore broader patterns of biodiversity (Margules and Sarkar 2007).

Potential primate distribution was modeled to estimate the future contribution of the landscape to primate conservation at a $1-\mathrm{km}^{2}$ grid cell resolution over the whole of Borneo using presence-only modeling. The MaxEnt algorithm (version 3.3.3e; Phillips et al. 2006) was applied using default settings (maximum number of background points $=10000$; random test percentage $=$ 25; regularization multiplier $=1$ ) to relate 1703 verified occurrences of 13 primate species to geophysical and climatic data. To account for spatial autocorrelation in historical sampling effort, localities were spatially filtered (leaving only one record within a radius of 10 $\mathrm{km}$ ), and sampling bias was incorporated into modeling for each species using a neighborhood analysis as described by Kramer-Schadt et al. (2013). Environmental parameters included climate variables, distance to wetlands, and soil pH. For each species, the probability of occurrence was converted into binary presence/ 
absence maps based on a conservative 10th percentile threshold. The resulting maps were then verified by a primate expert, and the distributions of three species (Hylobates alibarbis, H. muelleri, and Pongo pygmaeus) modified as a result of the expert assessment. Nine species were found to overlap with the study region, including the white-bearded gibbon (H. albibarbis), long-tailed macaque (Macaca fascicularis), pig-tailed macaque (M. nemestrina), proboscis monkey (Nasalis larvatus), Bornean slow loris (Nycticebus menagensis), Bornean orangutan (P. pygmaeus), maroon-leaf monkey (Presbytis rubicunda), western tarsier (Tarsius bancanus), and the silvered-leaf monkey (Trachypithecus cristatus).

The potential importance of each grid cell for biodiversity was identified by using a simulated annealing algorithm to identify the minimum set of cells that will represent $30 \%$ of the distribution of each biodiversity feature (Marxan version 2.1.1 and Zonae Cogito version 1.22; Ball et al. 2009, Segan et al. 2011). Multiple near-optimal solutions to the minimum set problem were obtained and overlaid to give the selection frequency for each cell, which can be interpreted as the cells' relative importance to achieving biodiversity targets (Table 1). We emphasize that identification of biodiversity importance in this case is not the same as identification of conservation priorities: typically identification of conservation priorities should include, inter alia, consideration of direct and opportunity costs, and an assessment of how endangered taxa are (Margules and Sarkar 2007).

\section{Analysis of spatial ecosystem service coincidence}

Spatial coincidence between ecosystem services was assessed using Spearman's rank test with a significance test corrected for spatial autocorrelation (Clifford et al. 1989, Dutilleul et al. 1993, Osorio et al. 2012). Nonparametric methods were used, as normality was neither expected nor present within many of the ecosystem service layers. To reduce the impact of spatial autocorrelation, we used a bootstrapping technique, with 10 subsamples $(n=1000)$ taken at random without replacement from the full data set to calculate average $\rho$ and significance values (Gos and Lavorel 2012). We described correlation results as weak if absolute values were $0.2-0.3$, moderate if $0.3-0.6$, and strong if 0.6 or over, using a significance level of $\alpha=0.05$.

Hotspots of ecosystem services were defined as the areas representing the upper 30th and 10th percentile threshold for each layer individually. Hotspot congruency among services was assessed using Cohen's $\kappa$ (Cohen 1960, Czaplewski 1994, Gamer et al. 2012), and by measuring the absolute area of overlap. The value of the $\kappa$ statistic ranges from -1 (perfect dissimilarity) to 1 (perfect similarity), with 0 indicating expected similarity due to chance. Values greater than 0.6 were considered

\footnotetext{
${ }^{7}$ http://www.uq.edu.au/marxan/
}

to represent substantial overlap, values between 0.2 and 0.4 to indicate minimal overlap, while equivalent negative values show analogous levels of disassociation (Landis and Koch 1977).

Previous studies highlight the potential variability of ecosystem service patterns at different scales (Anderson et al. 2009). The EMRP region is divided into five management blocks (blocks A-E; Fig. 1), each with a substantially distinct social-ecological history. To assess the consistency of observed patterns at smaller spatial extents, we repeated the analyses for each management block separately, and compared results from the subregional analyses with the patterns observed at the regional level.

\section{Analysis of existing land-use plans and identification of priority areas for management}

Recent land-use policies have encouraged the expansion of economic development and agriculture both within the EMRP and Indonesia as a whole (Giesen 2008, Jakarta Post 2009, Obidzinski and Chaudhury 2009). These include a 10-year plan to expand fiber and oil-palm plantations by 19 million ha (Jakarta Post 2009, Obidzinski and Chaudhury 2009). For the EMRP region, the reforestation of 400000 ha of areas with $>1$ $\mathrm{m}$ depth peat, and over additional areas of shallow peat is sought (Giesen 2008). Current legislation limits development on peat with a depth greater than $3 \mathrm{~m}$, aiming to protect the hydrological function of these areas (Republic of Indonesia 1990).

We evaluate the performance of four potential landuse scenarios for the EMRP area (Fig. 1):

Scenario 1.-Current land use (current). This assumes all current agricultural land, including sawah, is maintained as smallholder agriculture. All other land is assumed to be unmanaged, and forestry, oil palm, or conservation activities are not undertaken.

Scenario 2.-Current land use assuming all oil-palm concessions are developed (current with oil palm). Similar to scenario 1, but assuming all land currently zoned as an oil-palm concession is fully developed into an oil-palm plantation.

Scenario 3.-Development as per the zoning plan outlined in Presidential Instruction No. 2/2007 (Republic of Indonesia 2007) on rehabilitation and revitalization of the Ex-Mega Rice Project Area in Central Kalimantan (INPRES). This assumes three zones: agriculture, forestry, and conservation. We assume agriculture to be smallholder agriculture, or oil-palm plantation where there is an oil-palm concession. This is the current land management policy for the region, although it is largely unimplemented and considered a temporary or draft zoning map.

Scenario 4.-Development as per the zoning plan outlined in the EMRP "master plan" project (EMRP MP). This plan was designed to improve on INPRES, incorporating updated information from a range of stakeholders that has not yet been implemented into 
policy (Giesen 2008). Four zones are defined: agriculture, limited agriculture, forestry, and conservation. As for INPRES, we separate agriculture into both oil palm and smallholder agriculture, but allocate limited agriculture as smallholder agriculture only.

The four land-use scenarios were assessed according to the potential carbon emission mitigation and the supply of timber, smallholder agriculture, and palm oil. As biodiversity conservation does not feature as an activity in scenarios 1 and 2, only scenarios 3 and 4 were assessed for representation of biodiversity. We also estimate the value for biodiversity and carbon of conserving only the area of deep peat.

\section{RESUlTS}

\section{Overall spatial patterns of ecosystem services}

Carbon.-Total carbon stocks are highest in the areas with the greatest proportion of deep peat (blocks E and C; Table 2 and Figs. 1 and 2). Since carbon stocks in the region are driven mostly by carbon occurring in peat soils, carbon stocks had only a weak positive relationship with potential value of timber $(\rho=0.36, P=0.02$; $\kappa$ $=0.30-0.36$; Table 3; Appendix F: Table F1). Two blocks ( $\mathrm{B}$ and $\mathrm{E}$ ) displayed negative correlations of potential value for agriculture with carbon stock, while block $\mathrm{C}$ showed positive correlation and a substantial overlap in the upper 30th percentile hotspots (Table 3). This variation drives the lack of relationship identified at a whole-region scale. The average potential for emission reductions was fairly evenly distributed across blocks (Fig. 2), and the estimates for total values were consequently driven by area, with the largest total in block C (Table 2).

Timber.-Average and total value of timber is highest in block $\mathrm{E}$ and this is where most of the current illegal timber operations are also concentrated (Table 2 and Fig. 2). Overall areas with a high value for timber had a weak positive correlation with important areas for biodiversity $(\rho=0.35, P<0.05$; Table 3 ; Appendix F: Table F1).

Smallholder agriculture.-The potential profit for smallholder agriculture is greatest in blocks A, C, and $\mathrm{E}$, based on both average and total values (Table 2 and Fig. 2). Overall, there was low correlation and congruence between smallholder agriculture and other services, with the exception of palm oil (correlation $\rho=0.55, P<$ $0.001 ; \kappa=0.61$ for 30 th percentile hotspots), and particularly in block C (Table 3; Appendix F: Table F1).

Palm oil.-The potential for palm oil production is greatest in blocks A, C, and E, based on both average and total values (Table 2 and Fig. 2). While many of the current concessions occur in these higher-value regions, there are important exceptions, including concessions in blocks B and D (Figs. 1 and 2).

Biodiversity.-Biodiversity value is, on average, potentially greatest in block $\mathrm{E}$ and least in block D (Table 2 ), however there were some areas of particular importance to mangroves and swamp forest types in blocks C and D (Fig. 2). Potentially important areas for biodiversity and potential value for smallholder agriculture overlapped in blocks A, B, and D, although this interaction was not evident when the study region was aggregated (Table 3; Appendix F: Table F1).

\section{Performance of existing land-use plans and scenarios}

Scenario 1.-Reflecting the current land cover for the region and excluding any development of oil palm or forestry, this scenario would not achieve additional carbon emissions mitigation, oil palm, or timber value, and would only deliver $12 \%$ of the potential value for smallholder agriculture (Table 4).

Scenario 2.--Reflecting the current land cover, but assuming the development of all oil-palm concessions, it would deliver $28 \%$ of total potential palm oil value (Table 4). However, approximately $30 \%$ of the existing concessions are not in eligible areas (i.e., in areas of deep peat). Many of the oil-palm concessions also overlap with current smallholder agriculture (e.g., one-third of the concession area in block A), thus if developed, would substantially reduce smallholder agricultural production in the region (Table 4). The development of oil-palm concessions may improve carbon emission mitigation in the region by $25 \%$ relative to the current situation (scenario 1), due to fire management on otherwise degraded land (Table 4).

Scenario 3.-Reflecting full development of the current zoning regulation, this scenario would include large areas designated for conservation across areas of deep peat and remaining forests (Fig. 1). Assuming that these conservation areas are managed for fires, and are otherwise further restored, a large proportion of potential carbon emissions could be mitigated $(92 \%$ of the maximum; Table 4). However if these areas are not actively managed for fire, the carbon benefits will be much reduced (resulting in $10 \%$ of the maximum; Table 4). Most of the forestry zones under scenario 3 are located in block $\mathrm{C}$, which has low values for timber extraction and would be expected to generate only $4 \%$ of the total possible timber value (Table 4, Figs. 1 and 2). Smallholder agriculture will continue to dominate in block $\mathrm{A}$ and further expand agricultural development through block D (Fig. 1), despite the latter being extensively degraded and of low productivity for smallholder agriculture (Fig. 2). Exclusion of oil palm in deep-peat areas in scenario 3 reduces the potential value of palm oil to one-third of that achieved in scenario 2 (Table 4). Due predominantly to a larger conservation area, scenario 3 would outperform scenario 4 in representation of eight of the nine primate species, with improvements in the representation by $14 \%$ of each species distribution on average (Fig. 3). Under both scenarios there will be underrepresentation of some species most sensitive to deforestation, including the proboscis monkey and the silvered-leaf monkey (Fig. 3). 
TABLE 2. Distribution of ecosystem service values throughout the study region.

\begin{tabular}{|c|c|c|c|c|c|c|}
\hline \multirow[b]{2}{*}{ Ecosystem service } & \multicolumn{6}{|c|}{ Block (area in 1000 ha) } \\
\hline & A (315) & B (161) & $\mathrm{C}(445)$ & D (142) & E (413) & Total (1476) \\
\hline \multicolumn{7}{|l|}{ Smallholder agriculture } \\
\hline Total value (million US\$/yr) & 185 & 61 & 205 & 27 & 190 & 667 \\
\hline Median (US\$ $\cdot \mathrm{ha}^{-1} \cdot \mathrm{yr}^{-1}$ ) & 552 & 353 & 468 & 166 & 494 & 494 \\
\hline Mean (US\$ $\cdot \mathrm{ha}^{-1} \cdot \mathrm{yr}^{-1}$ ) & 583 & 379 & 458 & 197 & 461 & 451 \\
\hline $\mathrm{H} 10(\%)$ & 88 & 0 & 12 & 0 & 0 & 100 \\
\hline H30 (\%) & 34 & 0 & 45 & 0 & 21 & 100 \\
\hline H10 area (1000 ha) & 129 & 0 & 19 & 0 & 0 & 148 \\
\hline H10 proportion overlap $\dagger$ & 33 & 67 & 40 & 0 & 100 & 34 \\
\hline \multicolumn{7}{|l|}{ Timber } \\
\hline Total value (NPV, million US\$) & 105 & 82 & 140 & 25 & 367 & 718 \\
\hline Median (NPV, USS/ha) & 109 & 269 & 111 & 16 & 882 & 206 \\
\hline Mean (NPV, US\$/ha) & 373 & 581 & 334 & 215 & 885 & 511 \\
\hline $\mathrm{H} 10(\%)$ & 12 & 13 & 17 & 2 & 56 & 100 \\
\hline $\mathrm{H} 30(\%)$ & 13 & 11 & 16 & 3 & 57 & 100 \\
\hline $\mathrm{H} 10$ area $(1000 \mathrm{ha})$ & 17 & 18 & 24 & 3 & 84 & 145 \\
\hline H10 proportion overlap $\dagger$ & 38 & 13 & 31 & 4 & 27 & 27 \\
\hline \multicolumn{7}{|l|}{ Palm oil } \\
\hline Total value (NPV, million US\$) & 1074 & 251 & 1481 & 383 & 1401 & 4590 \\
\hline Median (NPV, US\$/ha) & 3198 & 0 & 3673 & 3111 & 3266 & 3266 \\
\hline Mean (NPV, US\$/ha) & 3418 & 1719 & 3311 & 2709 & 3396 & 3117 \\
\hline $\mathrm{H} 10(\%)$ & 27 & 5 & 45 & 3 & 20 & 100 \\
\hline $\mathrm{H} 30(\%)$ & 17 & 3 & 54 & 2 & 25 & 100 \\
\hline H10 area (ha) & 64 & 11 & 128 & 6 & 57 & 267 \\
\hline H10 proportion overlap $\dagger$ & 62 & 18 & 28 & 5 & 32 & 36 \\
\hline \multicolumn{7}{|l|}{ Carbon stocks } \\
\hline Total value (million Mg C) & 226 & 144 & 358 & 88 & 380 & 1196 \\
\hline Median (Mg C/ha) & 695 & 904 & 869 & 603 & 994 & 864 \\
\hline Mean $(\mathrm{Mg} \mathrm{C} / \mathrm{ha})$ & 719 & 878 & 798 & 614 & 913 & 804 \\
\hline $\mathrm{H} 10(\%)$ & 7 & 6 & 15 & 0 & 73 & 100 \\
\hline $\mathrm{H} 30(\%)$ & 8 & 16 & 17 & 0 & 58 & 100 \\
\hline H10 area (ha) & 10 & 9 & 22 & 0 & 109 & 151 \\
\hline H10 proportion overlap & 43 & 57 & 76 & 0 & 54 & 57 \\
\hline \multicolumn{7}{|l|}{ Potential emissions reductions } \\
\hline Total value (million $\mathrm{Mg} \mathrm{CO}_{2} \mathrm{e} / 40 \mathrm{yr}$ ) & 2045 & 1797 & 3817 & 173 & 2962 & 10795 \\
\hline Median $\left(\mathrm{Mg} \mathrm{CO}_{2} \mathrm{e} \cdot \mathrm{ha}^{-1} \cdot 40 \mathrm{yr}^{-1}\right)$ & 1917 & 10960 & 6769 & 1052 & 6440 & 3964 \\
\hline Mean $\left(\mathrm{Mg} \mathrm{CO}_{2} \mathrm{e} \cdot \mathrm{ha}^{-1} \cdot 40 \mathrm{yr}^{-1}\right)$ & 6435 & 10550 & 8238 & 1205 & 7147 & 7133 \\
\hline $\mathrm{H} 10(\%)$ & 34 & 24 & 31 & 0 & 11 & 100 \\
\hline H30 (\%) & 20 & 20 & 38 & 0 & 22 & 100 \\
\hline H10 area (1000 ha) & 48 & 37 & 50 & 0 & 16 & 151 \\
\hline H10 proportion overlap $\dagger$ & 5 & 7 & 48 & 0 & 21 & 22 \\
\hline \multicolumn{7}{|l|}{ Biodiversity } \\
\hline Score (as percentage of total, weighted by area) & 24 & 11 & 24 & 7 & 35 & 100 \\
\hline Median (percentage of overall maximum) & 38 & 35 & 29 & 24 & 43 & 34 \\
\hline Mean (percentage of overall maximum) & 36 & 33 & 26 & 22 & 40 & 32 \\
\hline H10 (\%) & 14 & 7 & 17 & 16 & 47 & 100 \\
\hline $\mathrm{H} 30(\%)$ & 20 & 11 & 12 & 6 & 52 & 100 \\
\hline H10 area (1000 ha) & 18 & 10 & 21 & 15 & 65 & 130 \\
\hline H10 proportion overlap $\dagger$ & 55 & 44 & 25 & 3 & 34 & 32 \\
\hline
\end{tabular}

Note: Proportion overlap comparison includes smallholder agriculture, timber, palm oil, biodiversity, and either potential carbon emissions or carbon stocks. H10 refers to upper 10th percentile of hotspot value, H30 to upper 30 th percentile of hotspot value. $\mathrm{CO}_{2} \mathrm{e}$, or carbon dioxide equivalent, refers to an amount of greenhouse gases equivalent to the given volume of $\mathrm{CO}_{2}$.

$\dagger$ Indicates proportion overlap in potential carbon emissions.

Indicates proportion overlap in potential carbon stocks.

Scenario 4.-This is a modification of the zoning plan in scenario 3 and would deliver similar results overall. Assuming conservation areas are managed for fires and restored, $88 \%$ of the potential emissions could be mitigated, but if fire is not managed, this would be reduced to $4 \%$ (Table 4). Forestry, again located in block C, would only generate $2 \%$ of total possible timber value (Table 4 , Figs. 1 and 2). Smallholder agriculture will similarly be encouraged onto low-value land as in scenario 3, however limited agriculture will also be allowed in block E (Fig. 1). Scenario 4 also limits oil-palm development in deep peat, and would deliver $8 \%$ of total palm oil value (Table 4). While there may be potential for oil-palm development in northern areas of block D, scenario 4 would zone the entirety of block D as a development zone for agriculture and oil palm (Fig. 1), and this will impact remaining 


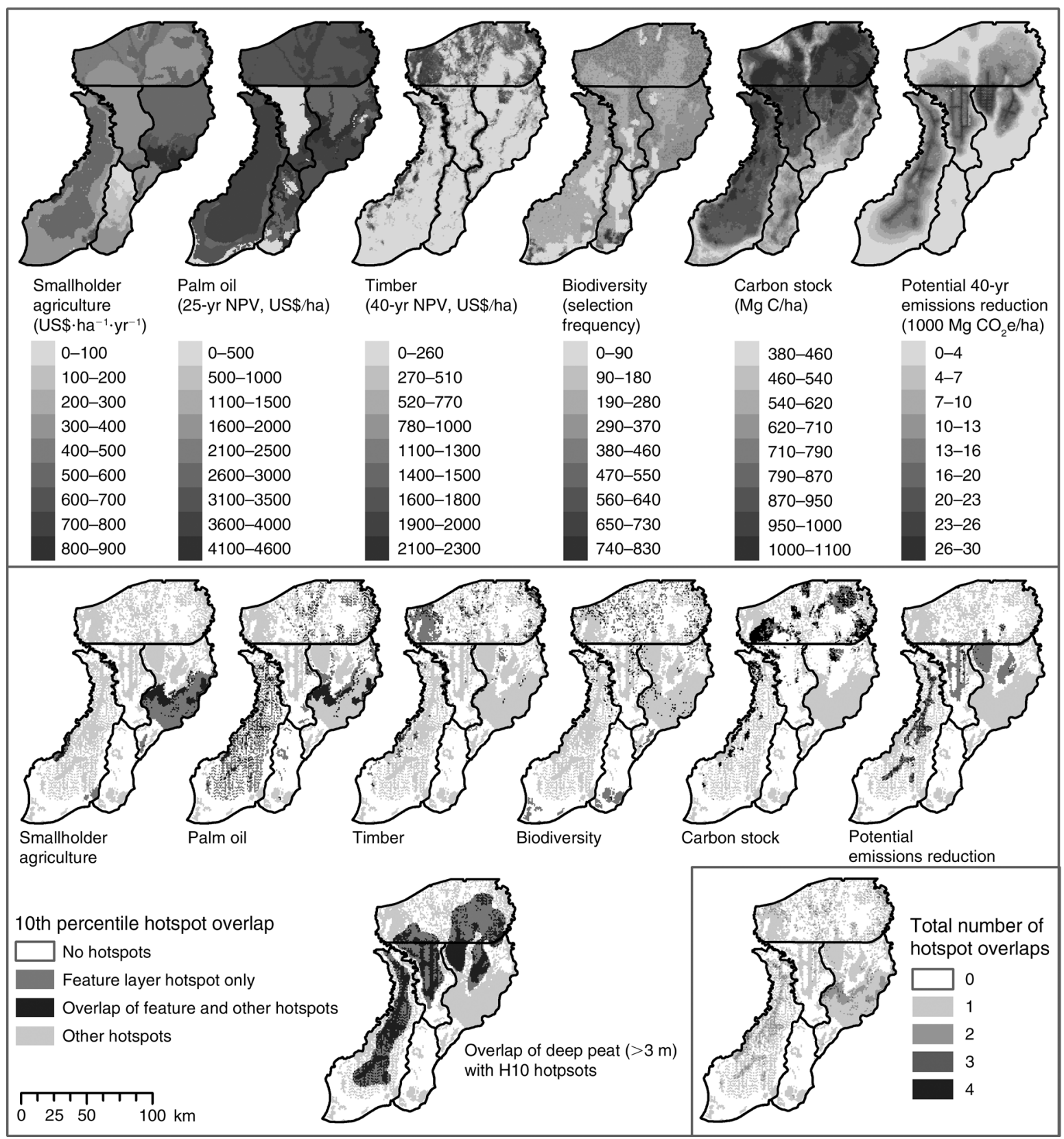

FIG. 2. Summary of the potential value of ecosystem services and overlap between the upper 10th percentile (H10) hotspots. Potential values for smallholder agriculture, palm oil, and timber are given in US\$. Palm oil potential values are given in net present value (NPV) over 25 years (Appendix E), and timber potential values are given in NPV over the first cutting cycle (40 years; Appendix C). Emissions reductions are shown in carbon dioxide equivalent $\left(\mathrm{CO}_{2} \mathrm{e}\right) / \mathrm{ha}$; carbon dioxide equivalent refers to an amount of greenhouse gases equivalent to the given volume of $\mathrm{CO}_{2}$. Overlap between hotspots involving services requiring exclusive land uses implies potential conflicts at a site level, whereas spatial separation of these services, or overlap between services with a potentially complementary land use may be seen as an opportunity for landscape-level multifunctionality.

examples of unique forest types in the lower section of this block. Scenario 4 would result in greater representation of mangroves at the expense of riverine-riparian and swamp forest types (Fig. 3).

Conservation of deep-peat areas only.-Deep peat (where peat is greater than $3 \mathrm{~m}$ ) covered 447297 ha (approximately $30 \%$ of the region; Fig. 1). This area represents the entire potential carbon mitigation hotspot, and would have a relatively low opportunity cost for the provisioning services (only $2.2 \%$ of provisioningrelated hotspots were located in deep-peat areas). Conservation of deep-peat areas would provide $67 \%$ of the total potential carbon emissions reductions, but only if the area is also managed for fire (Table 4). Protecting 
TABLE 3. Blockwise correlation and congruency among ecosystem services; $\kappa$ values are shown for overlap with H10 and H30 hotspots.

\begin{tabular}{|c|c|c|c|c|c|c|c|c|c|}
\hline \multirow[b]{3}{*}{ Ecosystem service } & \multirow{2}{*}{\multicolumn{3}{|c|}{ Overall }} & \multicolumn{6}{|c|}{ Block } \\
\hline & & & & \multicolumn{3}{|c|}{ A } & \multicolumn{3}{|c|}{$\mathrm{B}$} \\
\hline & $\rho$ & $\kappa, \mathrm{H} 10$ & $\kappa, \mathrm{H} 30$ & $\rho$ & $\kappa, \mathrm{H} 10$ & $\kappa, \mathrm{H} 30$ & $\rho$ & $\kappa, \mathrm{H} 10$ & $\kappa, \mathrm{H} 30$ \\
\hline \multicolumn{10}{|l|}{ Smallholder agriculture } \\
\hline $\begin{array}{l}\text { Timber } \\
\text { Biodiversity } \\
\text { Palm oil } \\
\text { Initial total carbon stock } \\
\text { Potential emission reductions }\end{array}$ & + & & + & $\begin{array}{l}{[+] \dagger} \\
+\dagger \\
+\end{array}$ & & $\begin{array}{l}+ \\
-\dagger \\
-\dagger\end{array}$ & $\begin{array}{l}{[+] \dagger} \\
+ \\
-\dagger \\
-\dagger\end{array}$ & $+\dagger$ & $\begin{array}{l}+\dagger \\
+\dagger \\
+ \\
+\dagger \\
+\dagger\end{array}$ \\
\hline \multicolumn{10}{|l|}{ Biodiversity } \\
\hline $\begin{array}{l}\text { Timber } \\
\text { Palm oil } \\
\text { Initial total carbon stock } \\
\text { Potential emission reductions }\end{array}$ & + & & + & $\dagger$ & & $\dagger$ & + & & $\dagger$ \\
\hline \multicolumn{10}{|l|}{ Timber } \\
\hline $\begin{array}{l}\text { Palm oil } \\
\text { Initial total carbon stock } \\
\text { Potential emission reductions }\end{array}$ & $\begin{array}{l}+ \\
+\end{array}$ & + & + & $\stackrel{\dagger}{+}+]$ & + & $\dagger$ & $\stackrel{\dagger}{\dagger}$ & $\dagger$ & $\stackrel{\dagger}{-\dagger}$ \\
\hline \multicolumn{10}{|l|}{ Palm oil } \\
\hline $\begin{array}{l}\text { Initial total carbon stock } \\
\text { Potential emission reductions }\end{array}$ & {$[+]$} & & & $-\dagger$ & & $\begin{array}{l}-\dagger \\
-\dagger\end{array}$ & $\begin{array}{l}-\dagger \\
-\dagger\end{array}$ & & $\begin{array}{l}-\dagger \\
-\dagger\end{array}$ \\
\hline \multicolumn{10}{|l|}{ Summary of changes } \\
\hline $\begin{array}{l}\text { No change } \\
\text { Change in significance } \\
\text { Change in sign }\end{array}$ & $\begin{array}{l}\text { NA } \\
\text { NA } \\
\text { NA }\end{array}$ & & $\begin{array}{l}4 \\
1\end{array}$ & $\begin{array}{l}9 \\
0 \\
0\end{array}$ & $\begin{array}{r}14 \\
6 \\
0\end{array}$ & $\begin{array}{l}8 \\
7 \\
1\end{array}$ & $\begin{array}{l}6 \\
2 \\
0\end{array}$ & $\begin{array}{r}12 \\
9 \\
0\end{array}$ & $\begin{array}{l}5 \\
4 \\
0\end{array}$ \\
\hline
\end{tabular}

Notes: Positive signs indicate either a substantial positive correlation $(\rho>0.2, P<0.05)$, a substantial positive congruence ( $\kappa>$ 0.2 ), or an absolute overlap over $7 \%$ or $20 \%$ for upper 30 th and upper 10th percentile hotspots respectively. Negative signs indicate either substantial negative correlation $(\rho<-0.2, P<0.05)$, or a substantial negative congruence $(\kappa<-0.2)$. Bracketed signs indicate where correlations are significant $(P<0.05)$, however the slope is not substantial $(|\rho|<0.2)$. In all blocks, $\kappa$ represents Cohen's $\kappa$.

$\dagger$ Indicates a change in significance from the overall case to the blockwise comparisons.

$\$$ Indicates a change in sign of the relationship.

only deep-peat areas would not perform well for biodiversity. Four primates would have less than $10 \%$ of their potential distributions represented (Fig. 3), and on average, feature representation would be one-third of that achieved under scenarios 3 and 4 . Of the forest types, only low-pole forest would be reasonably represented $(69 \%)$, due to its geographic restriction to deep-peat areas (Fig. 3).

\section{DisCUSSION}

Our study provides the first quantification, mapping, valuation, and analysis of a set of policy-relevant ecosystem services in Central Kalimantan, a globally important region for carbon emissions reduction, development, and biodiversity. There is pressure to restore, rehabilitate, and develop this region, with

TABLE 4. Potential supply of smallholder agriculture, timber, and palm oil under each land-use scenario.

\begin{tabular}{|c|c|c|c|c|c|c|}
\hline \multirow[b]{2}{*}{ Ecosystem service } & \multicolumn{6}{|c|}{ Land-use scenario } \\
\hline & 1 & 2 & 3 & 4 & Peat & Total \\
\hline Smallholder agriculture (million US\$/yr) & $81(12 \%)$ & $49(7 \%)$ & $135(20 \%)$ & $207(31 \%)$ & NA & 667 \\
\hline Timber (NPV, million US\$ over $40 \mathrm{yr}$ ) & 0 & 0 & $32(5 \%)$ & $11(2 \%)$ & NA & 718 \\
\hline Palm oil (NPV, million US\$ over 25 yr ) & 0 & $1269(28 \%)$ & $412(9 \%)$ & $367(8 \%)$ & NA & 4590 \\
\hline $\begin{array}{l}\text { Potential emissions reduction (assuming fire } \\
\text { management and forest regeneration conservation } \\
\text { areas; million } \mathrm{Mg} \mathrm{CO}_{2} \mathrm{e} \text { over } 40 \mathrm{yr} \text { ) }\end{array}$ & 0 & $2682(25 \%)$ & $9909(92 \%)$ & $9457(88 \%)$ & $7184(67 \%)$ & 10797 \\
\hline $\begin{array}{l}\text { Potential emissions reduction (assuming no fire } \\
\text { management or forest regeneration in conservation } \\
\text { areas; million } \mathrm{Mg} \mathrm{CO}_{2} \mathrm{e} \text { over } 40 \mathrm{yr} \text { ) }\end{array}$ & 0 & $2682(25 \%)$ & $1107(10 \%)$ & $429(4 \%)$ & 0 & \\
\hline
\end{tabular}

Note: Scenario 1 is current, 2 is current with oil palm, 3 is development as per the zoning plan outlined in Presidential Instruction No. 2/2007 on rehabilitation and revitalization of the EMRP Area in Central Kalimantan (INPRES), and 4 is the EMRP master plan. Peat refers to deep $(\geq 3 \mathrm{~m})$ peat. The potential for emissions reduction only on deep peat, and with and without fire management and forest regeneration in conservation areas was assessed for land-use scenarios 3 and 4 . Values in parentheses indicate percentage of the total potential value of that service over the entire region. 
TABLE 3. Extended.

\begin{tabular}{|c|c|c|c|c|c|c|c|c|c|c|c|}
\hline \multicolumn{9}{|c|}{ Block } & & & \\
\hline \multicolumn{3}{|c|}{$\mathrm{C}$} & \multicolumn{3}{|c|}{$\mathrm{D}$} & \multicolumn{3}{|c|}{$\mathrm{E}$} & \multicolumn{3}{|c|}{ Summary of change } \\
\hline$\rho$ & $\kappa, \mathrm{H} 10$ & $\kappa, \mathrm{H} 30$ & $\rho$ & $\kappa, \mathrm{H} 10$ & $\kappa, \mathrm{H} 30$ & $\rho$ & $\kappa, \mathrm{H} 10$ & $\kappa, \mathrm{H} 30$ & None & Significance & Sign \\
\hline & & & & & $-\dagger$ & & & & 11 & 4 & 0 \\
\hline & & & & $+\dagger$ & $+\dagger$ & & & & 11 & 4 & 0 \\
\hline+ & $+\dagger$ & + & $\dagger$ & $-\dagger$ & $-\$$ & + & $+\dagger$ & + & 9 & 5 & 1 \\
\hline$+\dagger$ & & $+\dagger$ & & & & $-\dagger$ & & $-\dagger$ & 8 & 7 & 0 \\
\hline$+\dagger$ & & $+\dagger$ & & & $-\dagger$ & $-\dagger$ & & $-\dagger$ & 7 & 8 & 0 \\
\hline \multirow[t]{4}{*}{+} & & + & $\dagger$ & & $\dagger$ & $\dagger$ & & $\dagger$ & 8 & 7 & 0 \\
\hline & & & & & & {$[+] \dagger$} & & & 14 & 1 & 0 \\
\hline & & & & & & & & & 15 & 0 & 0 \\
\hline & & & & & & $-\dagger$ & & & 14 & 1 & 0 \\
\hline$\dagger$ & & $+\dagger$ & + & & & $\dagger$ & & & 10 & 5 & 0 \\
\hline \multirow[t]{2}{*}{+} & + & + & $\dagger$ & $\dagger$ & $\dagger$ & + & + & + & 8 & 7 & 0 \\
\hline & & & & & & & & $-\dagger$ & 12 & 3 & 0 \\
\hline$+\dagger$ & & $+\dagger$ & & $+\dagger$ & $+\dagger$ & & & & 8 & 7 & 0 \\
\hline+ & & $+\dagger$ & + & $+\dagger$ & $+\dagger$ & $\dagger$ & & & 7 & 6 & 2 \\
\hline 10 & 13 & 9 & 11 & 9 & 6 & 7 & 13 & 10 & 142 & $\dagger$ & $t$ \\
\hline 1 & 5 & 3 & 5 & 7 & 7 & 1 & 4 & $65 \dagger$ & & $65 \dagger$ & + \\
\hline 0 & 0 & 0 & 0 & 1 & 0 & 0 & 0 & $3 t$ & & $3 t$ & $3 \$$ \\
\hline
\end{tabular}
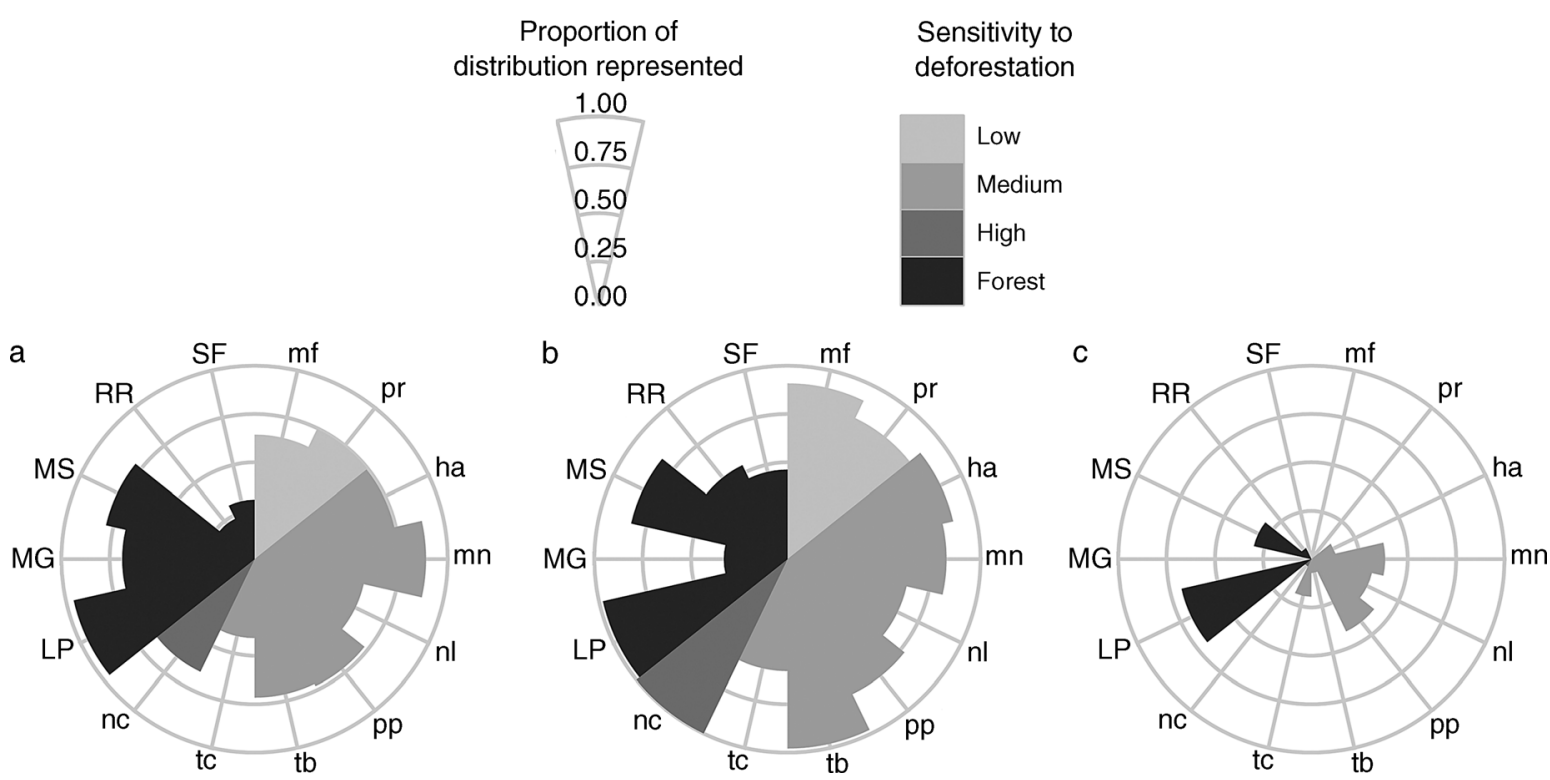

FIG. 3. Performance of protecting deep peat for representing the distribution of each biodiversity feature and of the conservation zones proposed under (a) scenario 3 (EMRP MP), (b) scenario 4 (INPRES), and (c) protecting deep peat only. The potential distribution of nine primate species was measured: Macaca fascicularis (mf; long-tailed macaque), Presbytis rubicunda, (pr; maroon-leaf monkey), Hylobates albibarbis (ha; white-bearded gibbon), Macaca nemestrina (mn; pig-tailed macaque), Nasalis larvatus (nl; proboscis monkey), Pongo pygmaeus (pp; Bornean orangutan), Tarsius bancanus (tb; western tarsier), Trachypithecus cristatus (tc; silvered-leaf monkey), and Nycticebus c. menagensis (nc; Bornean slow loris). In addition, the extant distribution of five forest types was evaluated: low pole (LP), mangrove (MG), mixed swamp (MS), riverine-riparian (RR), and swamp forest (SW). Proportion of distributions for primate species and forest types protected under each scenario are presented together, with concentric gray circles from the center out representing $0.00,0.25,0.50 .0 .75$, and 1.00 of the distribution represented. Primate species were grouped by sensitivity to deforestation (low, medium, or high), based on the methods of Wilson et al. (2010). Forest types are presented in black. 
interest from diverse sectors such as oil palm (Jagau et al. 2008), carbon mitigation (Hooijer et al. 2006, Busch et al. 2012, Joosten et al. 2012), and biodiversity protection (Meijaard 1997, Morrogh-Bernard et al. 2003, Page et al. 2009, Posa 2011, Posa et al. 2011, Wich et al. 2012). We developed maps of estimated value for a regulating service (carbon stocks and potential for emissions reduction), three provisioning services (timber, crops from smallholder agriculture, palm oil), and a supporting service (biodiversity). We evaluated four potential future land-use scenarios for the region, and assessed the conservation value of current legislation to limit development on areas of deep peat.

\section{Methodological highlights}

The potential of land to supply ecosystem services under different future contexts is critical information for forward-looking land-use planning (Wendland et al. 2010). We have defined ecosystem service value in terms of potential supply, reflecting a focus on future land-use planning in the region. This contrasts with many previous ecosystem service studies, which described current patterns of supply (Naidoo et al. 2008, Bennett et al. 2009, Lavorel et al. 2011). This was particularly important for estimating carbon emissions in this study region, as stock-difference approaches commonly used in similar ecosystem service assessments would not fully account for the dynamic carbon processes in peatlands (Murdiyarso et al. 2010). By using underlying land suitability data as the basis for valuing smallholder farming systems, we derived estimates of the potential for future expansion of farming practices, rather than being limited to valuation of current farming practices based on current distributions. The separate distribution layers developed for each species and forest type allowed the complementarity among land uses to be appraised, in addition to the individualistic responses of biodiversity features to land-use change.

\section{Implications for policy, planning, and management}

The prospective land-use plans for the region (scenarios 3 and 4) performed extremely well in mitigating potential carbon emissions, assuming that the zones designated for conservation are managed for fire. The performance of legislation to limit development on deep peat is similar, but overall emissions reduction would depend on appropriate land management outside of deep-peat areas. This national-level regulation designed to protect deep-peat areas has not been accounted for by local legislators, who have allocated oil-palm concessions over $30 \%$ of these areas. A lack of alignment between national and local institutional arrangements is thus a significant challenge for land-use management in this region, as is a lack of information on the trade-offs associated with land use (Galudra et al. 2011, Medrilzam and Dargusch 2011).

Programs and projects under the umbrella of reduced emissions from avoided deforestation and forest degra- dation $(\mathrm{REDD}+)$ epitomize the challenges of multipleuse, multi-objective landscapes (Wise et al. 2009, Ghazoul et al. 2010, Bucki et al. 2012, Law et al. 2012). One of the major concerns for REDD + is the trade-off between economic development activities and emission reduction activities enacted through preservation and restoration of forests (Koh and Ghazoul 2010, Venter et al. 2012). Degraded peatlands are often identified as priorities for REDD+ projects, due to the high emissions and relatively low value for productive use (Busch et al. 2012). Our estimates show the EMRP area contributes in the order of $12.5 \%$ to Indonesia's overall emissions (of approximately $2.1 \times 10^{9} \mathrm{Mg} \mathrm{CO}_{2}$ in 2005), emphasizing the criticality of addressing this area in national mitigation actions. In this region, we found limited overlap between areas important for smallholder agriculture and palm oil production with areas important for emissions reduction and biodiversity conservation. This suggests that effective land use and management actions for mitigating climate change may coexist alongside agriculture and oil-palm plantations.

Analysis of the oil-palm development scenario (scenario 2) suggests that emissions may be reduced though minimal active management of currently degraded and deforested areas, including transitioning to oil-palm plantations. This conclusion rests on the assumption that planting oil palm will reduce fire frequency. Oilpalm developments also preclude the delivery of other services (particularly the hydrological benefits delivered by restoring degraded peatlands), and may have both off-site impacts and lead to peat collapse in the future (Comte et al. 2012).

The large extent of the conservation zone under the land-use plans (scenarios 3 and 4) will underrepresent many of the biodiversity elements considered, in particular riverine-riparian, swamp forest, and mangroves. Relying only on legislation that limits development on deep peat would deliver even poorer outcomes for biodiversity. These results also support the growing body of evidence that priority areas for emissions reduction need not reflect important areas for biodiversity conservation (Anderson et al. 2009, Egoh et al. 2009, Venter et al. 2009a, Paoli et al. 2010, Strassburg et al. 2010). This suggests that carbon-related finance may not be the most appropriate tool for biodiversity conservation in this region, unless finance is linked to sustainable forestry management or coupled with additional biodiversity-specific incentives such as wildlife premiums (van der Meer and Ibie 2008, Dinerstein et al. 2010).

Some of the most consistent overlaps in services observed in the study area were among provisioning services, in particular between smallholder agriculture, timber, and palm oil, likely due to the underlying importance of soil quality for these services. While all of these potential services can contribute to economic development goals, they differ in the potential to contribute to local livelihoods (Rist et al. 2010, Obidzinski et al. 2012), attract external investment 

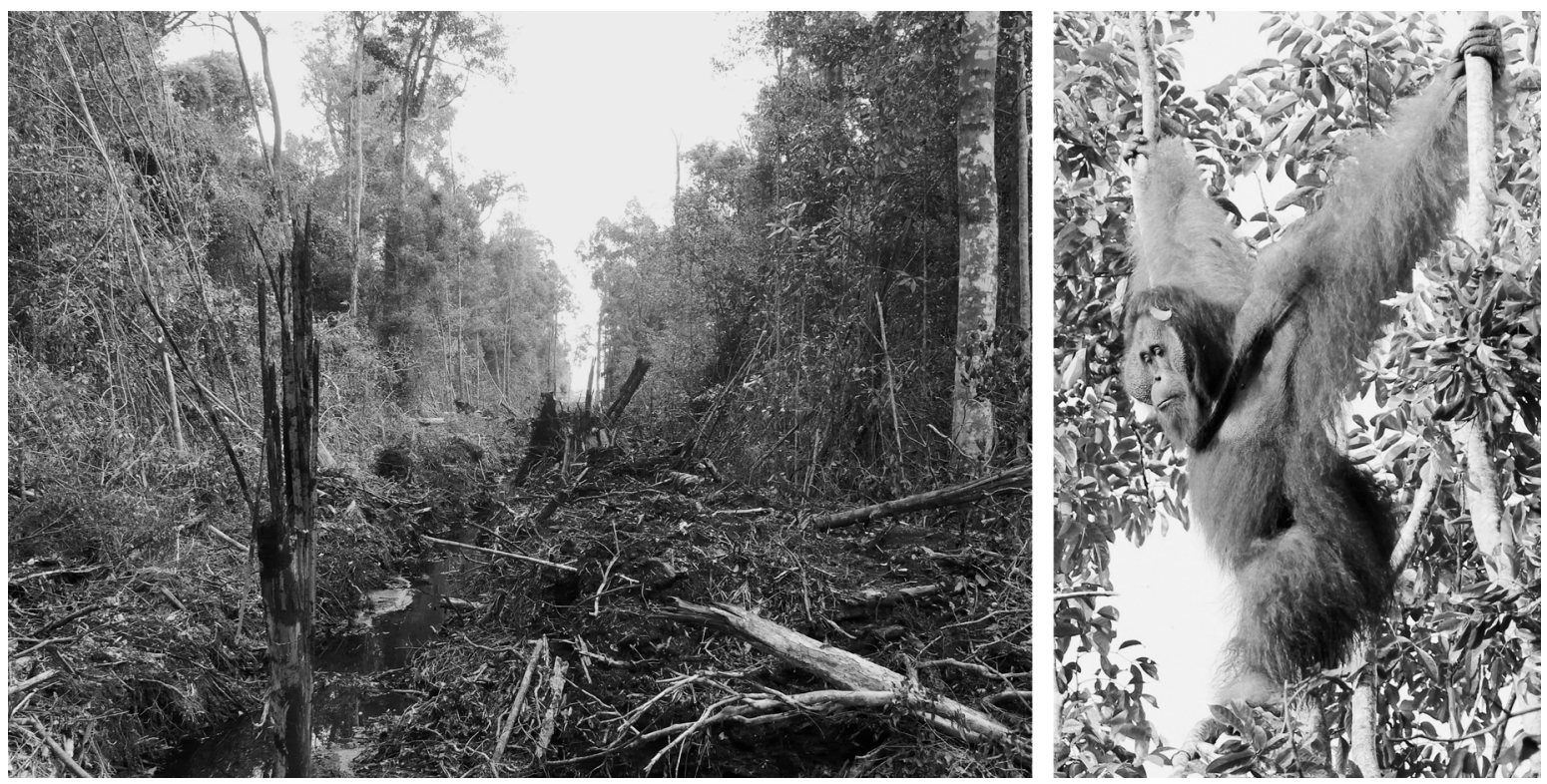

Plate 1. (Left) Clearing of peat forests for oil palm. (Right) Adult male orangutan in a Kalimantan, Borneo, oil-palm plantation. Photo credits: left, E. Meijaard; right, Nardiyono.

(Thomas et al. 2010), and deliver biodiversity or carbon co-benefits (Venter et al. 2009b). Each of these services may form a crucial role in development of the EMRP area, however the prospective land-use plans indicate many trade-offs that will require careful consideration in land-use policy, planning, and management.

Current oil-palm concessions are located on some of the most valuable land for smallholder agriculture. If these concessions are developed, it may shift smallholder agriculture into undeveloped areas where the development costs would be borne by local landholders. Both of the prospective land-use plans for the region will encourage expansion of smallholder agriculture into marginal lands, while allowing development of oil palm on current smallholder areas. This important trade-off between smallholders and larger commercial interests will influence the future well-being of local residents. The history of the EMRP area would suggest that encouraging smallholder development in marginal areas, particularly when involving transmigrants unfamiliar with peat-soil environments, will likely result in poverty and land abandonment.

There are other prospective zoning recommendations for the area that will entail significant trade-offs between ecosystem services, such as the designation of the southern portion of block $\mathrm{C}$ as forestry. While forestry operations in this subregion could be beneficial from a biodiversity and carbon emissions reduction perspective, it will require substantial upfront investment in restoration and fire management and is unlikely to replace illegal forestry operations that are concentrated in the north of the study region (in block E). This juxtaposition would suggest that the planned forestry development contradicts the current distribution of experience and facilities. The EMRP MP (scenario 4) will also allow limited agricultural development on the alreadydegraded portions of block E. While this is beneficial for smallholder agriculture, it will likely also facilitate access for additional illegal forestry operations (Obidzinski et al. 2012). Relatively high values for palm oil and agriculture in this area would suggests a high risk of permanent forest loss after logging (Langner and Siegert 2009, Koh et al. 2011, Miettinen et al. 2012).

\section{Research directions}

We have followed a utilitarian approach to defining ecosystem services, considering only ecosystem services that either (1) contribute directly to existing economies (provisioning services: smallholder agriculture, palm oil, and timber), (2) will potentially be considered as economic goods and services (regulatory services; carbon stocks and fluxes), or that (3) otherwise have intrinsic value, particularly due to their irreplaceability (Turner et al. 2003, Díaz et al. 2006).

In view of highlighting the difficulties in undertaking analyses of this nature, we have also focused on the services that have reasonable available data, and drive many of the key land management decisions of the region. Hydrological services (in particular flood mitigation) in this peat-dominated system would be an informative addition. Recent studies indicate that rapid peat subsidence following deforestation will lead to large-scale flooding in coastal peats (A. Hooijer, unpublished data). Deep-peat regions are likely to have important hydrological functions in the landscape by regulating fluctuations due to seasonal monsoons. The peat domes in block $\mathrm{E}$ are likely to supply key regulating hydrological services for the most valuable agricultural 
land in block $\mathrm{A}$ as a consequence of the river connections between these areas. Fisheries and nontimber forest products were also omitted from this study due to poor data availability (Jagau et al. 2008, van den Berg and Widiadi 2008).

Carbon dynamics in the region are strongly responsive to fire (Page et al. 2002, Hooijer et al. 2006, 2010). This suggests that fire management is a key element of restoration of peatlands in this region, and indeed, our model suggests that even high-impact land uses such as oil palm may have a net positive influence on carbon management in previously degraded land provided that (1) fire is managed and (2) this fire management continues for the duration of the planning horizon. Fires in this region are predominantly anthropogenic in origin, although preconditions such as droughts, excessively drained, dry peat, and associated vegetation facilitate their ignition and spread. This results in several options for fire management based on reaction (extinguishing current fires), education (encouraging better fire management by individuals), exclosure (preventing access), ecological management (restoring vegetation cover that inhibits fire), enhancements to land value (e.g., by planting valuable crops that people will protect from fire), and hydrology management (blocking drainage canals and raising the water table). Research is ongoing to develop effective fire management strategies for the region. The full costs of effective fire management will be highly dependent on the mix of approaches taken, but will likely be substantial and would be a key component of a socioeconomic evaluation of future land management plans.

The overall lack of relationship between biodiversity and provisioning services found in our study overlooks important site-specific interactions, and may also be a result of examining future potential value for biodiversity and production, as opposed to current patterns. Analysis of the literature reveals that current patterns are largely driven by land-use context (e.g., RaudseppHearne et al. 2010, Willemen et al. 2010). The positive relationships found by Anderson et al. (2009) and Gos and Lavorel (2012), for example, are associated with areas that have either a long history of agriculture or a steep gradient from high to low productivity, which simultaneously affects both agricultural production and biodiversity. Such relationships are also dependent on the type of agriculture considered: for example, greater overlap with important areas for biodiversity is generally associated with low-intensity agriculture (e.g., forage rather than cropping; Chan et al. 2006, O'Farrell et al. 2010). This suggests that while generalizations can be made from ecosystem service assessments, it is important to appropriately account for the local context.

\section{CONClusion}

We present a comprehensive application to identify potential synergies and conflicts between ecosystem services in the EMRP area and reveal important policy implications by analyzing future scenarios of land use. Methodological advances such as the spatial data analyses adopted here can partly overcome data limitations and help improve policy planning and implementation in data-limited contexts. Through simultaneously valuing and analyzing a range of ecosystem services, our study suggests that the provision of ecosystem services may be improved by targeted land management activities that enhance biodiversity and carbon emissions reduction outcomes, rather than focusing only on reforestation and peat restoration. Such activities would provide greater incentive for local smallholder, commercial, and government actors. The results reveal the shortcomings of blanket policies and incentives that do not explicitly consider local-scale trade-offs, and that transparent decision-making frameworks will be required to ensure land and resource management is effective, efficient, and equitable.

\section{ACKNOWLEDGMENTS}

This research was conducted with funding support from the Australian Research Council Centre of Excellence for Environmental Decisions and the Australian Research Council Future Fellowship program. Data was provided by the Central Kalimantan government and the EMRP management plan team. Nick Mawdsley and Aljosja Hooijer provided data and discussion. Shaun Coutts provided advice on the carbon modeling and Hawthorne Beyer provided advice on the agricultural models. E. Law was supported by an Australian Postgraduate Award, ARC CEED, and the UQ-CSIRO INRM scheme. K. A. Wilson was supported by an ARC Future Fellowship. B. Bryan was supported by CSIRO's Sustainable Agriculture Flagship. M. Struebig was supported by a Leverhulme Trust Early Career Fellowship. E. Meijaard was supported by a grant from the Arcus Foundation. We thank the anonymous reviewers for their valuable critiques and suggestions.

\section{Literature Cited}

Aditama, T. Y. 2000. Impact of haze from forest fire to respiratory health: Indonesian experience. Respirology 5:169-174.

Anderson, B. J., P. R. Armsworth, F. Eigenbrod, C. D. Thomas, S. Gillings, A. Heinemeyer, D. B. Roy, and K. J. Gaston. 2009. Spatial covariance between biodiversity and other ecosystem service priorities. Journal of Applied Ecology 46:888-896.

Ball, I. R., H. Possingham, and M. Watts. 2009. Marxan and relatives: software for spatial conservation prioritisation. Pages 185-195 in A. Moilanen, K. Wilson, and H. Possingham, editors. Spatial conservation prioritisation: quantitative methods and computational tools. Oxford University Press, Oxford, UK.

Ballhorn, U., F. Siegert, M. Mason, and S. Limin. 2009. Derivation of burn scar depths and estimation of carbon emissions with LIDAR in Indonesian peatlands. Proceedings of the National Academy of Sciences USA 106:21213-21218.

Bates, D., M. Maechler, and B. Bolker. 2012. lme4: linear mixed-effects models using S4 classes. $\mathrm{R}$ package version 0.999999-0. http://CRAN.R-project.org/package=lme4

Bennett, E. M., G. D. Peterson, and L. J. Gordon. 2009. Understanding relationships among multiple ecosystem services. Ecology Letters 12:1394-1404.

Bidang Statistik Sosial. 2012. Welfare indicators of Kalimantan Tengah 2011/12.115. [In Indonesian.] Central Kaliman- 
tan Central Bureau of Statistics. http://kalteng.bps.go.id/ flippublikasi/kesra2011/

Böhm, H. D. V., and F. Siegert. 2004. The impact of logging on land use change in Central Kalimantan, Indonesia. Peatlands International 12:3-10.

Bryan, B. A., 2013. Incentives, land use, and ecosystem services: synthesizing complex linkages. Environmental Science and Policy 27:124-134.

Bryan, B. A., and N. D. Crossman. 2013. Interacting markets, land use, and the supply of ecosystem services. Ecosystem Services 4:60-72.

Bryan, B. A., A. Grandgirard, and J. R. Ward. 2010. Quantifying and exploring strategic regional priorities for managing natural capital and ecosystem services given multiple stakeholder perspectives. Ecosystems 13:539-555.

Bucki, M., D. Cuypers, P. Mayaux, F. Achard, C. Estreguil, and G. Grassi. 2012. Assessing REDD+ performance of countries with low monitoring capacities: the matrix approach. Environmental Research Letters 7:014031.

Burkhard, B., N. D. Crossman, S. Nedkov, K. Petz, and R. Alkemade. 2013. Mapping and modelling ecosystem services for science, policy and practice. Ecosystem Services 4:1-3.

Busch, J., R. N. Lubowski, F. Godoy, M. Steininger, A. A. Yusuf, K. Austin, J. Hewson, D. Juhn, M. Farid, and F. Boltz. 2012. Structuring economic incentives to reduce emissions from deforestation within Indonesia. Proceedings of the National Academy of Sciences USA 109(4):1062-1067.

Chan, K. M. A., M. R. Shaw, D. R. Cameron, E. C. Underwood, and G. C. Daily. 2006. Conservation planning for ecosystem services. PLoS Biology 4:2138-2152.

Clifford, P., S. Richardson, and D. Hemon. 1989. Assessing the significance of the correlation between two spatial processes. Biometrics 45:123-134.

Cohen, J. 1960. A coefficient of agreement for nominal scales. Educational and Psychological Measurement 20:37-46.

Comte, I., F. Colin, J. K. Whalen, O. Grünberger, and J. P. Caliman. 2012. Agricultural practices in oil palm plantations and their impact on hydrological changes, nutrient fluxes and water quality in Indonesia: a review. Pages 71-124 in L. S. Donald, editor. Advances in agronomy. Academic Press, Waltham, Massachusetts, USA.

Convention on Biological Diversity (CND). 2003. Handbook of the convention on biological diversity. Earthscan, London, UK.

Crossman, N. D., et al. 2013. A blueprint for mapping and modelling ecosystem services. Ecosystem Services 4:4-14.

Czaplewski, R. L. 1994. Variance approximations for assessments of classification accuracy. RM-316. USDA Forest Service, Rocky Mountain Forest and Range Experiment Station, Fort Collins, Colorado, USA.

de Groot, K. 2008. Technical report number 13: community development and village institutions in the Ex-Mega Rice Project area in Central Kalimantan. Euroconsult Mott MacDonald and Deltares, Arnhem, Netherlands.

Díaz, S., J. Fargione, F. S. Chapin, III, and D. Tilman. 2006. Biodiversity loss threatens human well-being. PLoS Biology 4:e277.

Dinerstein, E., K. Varma, E. Wikramanayake, and S. Lumpkin. 2010. Wildlife premium market. http://www.hcvnetwork.org/ resources/folder.2006-09-29.6584228415/Wildlife_PremiumREDD\%20Oct\%2013\%202010\%20-2-\%20-2.pdf/view

Dutilleul, P., P. Clifford, S. Richardson, and D. Hemon. 1993. Modifying the $t$ test for assessing the correlation between two spatial processes. Biometrics 49:305-314.

Egoh, B., B. Reyers, M. Rouget, M. Bode, and D. M. Richardson. 2009. Spatial congruence between biodiversity and ecosystem services in South Africa. Biological Conservation 142:553-562.
Eigenbrod, F., P. R. Armsworth, B. J. Anderson, A. Heinemeyer, S. Gillings, D. B. Roy, C. D. Thomas, and K. J. Gaston. 2010. The impact of proxy-based methods on mapping the distribution of ecosystem services. Journal of Applied Ecology 47:377-385.

ESRI. 2011. ArcGIS desktop: release 10. Environmental Systems Research Institute, Redlands, California, USA.

Fisher, B., D. P. Edwards, X. Giam, and D. S. Wilcove. 2011. The high costs of conserving Southeast Asia's lowland rainforests. Frontiers in Ecology and the Environment 9:329-334.

Fisher, B., R. K. Turner, and P. Morling. 2009. Defining and classifying ecosystem services for decision making. Ecological Economics 68:643-653.

Folke, C., S. Carpenter, B. Walker, M. Scheffer, T. Elmqvist, L. Gunderson, and C. S. Holling. 2004. Regime shifts, resilience, and biodiversity in ecosystem management. Annual Review of Ecology, Evolution, and Systematics 35:557-581.

Galudra, G., M. V. Noordwijk, S. Suyanto, I. Sardi, U. Pradhan, and D. Catacutan. 2011. Hot spots of confusion: contested policies and competing carbon claims in the peatlands of Central Kalimantan, Indonesia. International Forestry Review 13:431-441.

Game, E. T., E. McDonald-Madden, M. L. Puotinen, and H. P. Possingham. 2008. Should we protect the strong or the weak? Risk, resilience, and the selection of marine protected areas. Conservation Biology 22:1619-1629.

Gamer, M., J. Lemon, I. Fellows, and P. Singh. 2012. irr: various coefficients of interrater reliability and agreement. $\mathrm{R}$ package version 0.84. http://CRAN.R-project.org/package=irr

Ghazoul, J., R. A. Butler, J. Mateo-Vega, and L. P. Koh. 2010. REDD: a reckoning of environment and development implications. Trends in Ecology and Evolution 25:396-402.

Giesen, W. 2008. Technical report 8: biodiversity and the ExMega Rice Project area in Central Kalimantan. In Master plan for the rehabilitation and revitalisation of the Ex-Mega Rice Project Area in Central Kalimantan. Euroconsult Mott MacDonald, Deltares | Delft Hydraulics, DHV, Wageningen UR, WitteveenbBos, PT MLD, and PT INDEC. Palangka Raya, Central Kalimantan, Indonesia.

Gos, P., and S. Lavorel. 2012. Stakeholders' expectations on ecosystem services affect the assessment of ecosystem services hotspots and their congruence with biodiversity. International Journal of Biodiversity Science, Ecosystem Services and Management 8:93-106.

Hijmans, R. J., and J. van Etten. 2012. raster: geographic data analysis and modeling. $\mathrm{R}$ package version 2.0-31. http:// CRAN.R-project.org/package=raster

Hooijer, A., S. Page, J. Canadell, M. Silvius, J. Kwadijk, H. Wosten, and J. Jauhiainen. 2010. Current and future $\mathrm{CO}_{2}$ emissions from drained peatlands in Southeast Asia. Biogeosciences 7:1505-1514.

Hooijer, A., M. Silvius, H. Wosten, and S. Page. 2006. PEAT$\mathrm{CO}$ 2: Assessment of $\mathrm{CO}_{2}$ emissions from drained peatlands in SE Asia. Delft Hydraulics report Q3943. Delft Hydraulics, Delft, Netherlands.

Jagau, Y., M. Noor, and J. Verhagen. 2008. Technical report number 5: agriculture in the Ex-Mega Rice Project area in Central Kalimantan. Euroconsult Mott MacDonald and Deltares, Arnhem, Netherlands.

Jakarta Post. 2009. 18 million hectares of land for palm oil. Published 2 December 2009, Jakarta Post, Jakarta, Indonesia.

Joosten, H., M. L. Tapio-Biström, and S. Tol. 2012. Peatlandsguidance for climate change mitigation through conservation, rehabilitation and sustainable use. Food and Agriculture Organization of the United Nations, Rome, Italy.

Justus, J., and S. Sarkar. 2002. The principle of complementarity in the design of reserve networks to conserve 
biodiversity: a preliminary history. Journal of Biosciences 27:421-435.

Klein, C. J., A. Chan, L. Kircher, A. J. Cundiff, N. Gardner, Y. Hrovat, A. Scholz, B. E. Kendall, and S. Airame. 2008. Striking a balance between biodiversity conservation and socioeconomic viability in the design of marine protected areas. Conservation Biology 22:691-700.

Koh, L. P., and J. Ghazoul. 2010. Spatially explicit scenario analysis for reconciling agricultural expansion, forest protection, and carbon conservation in Indonesia. Proceedings of the National Academy of Sciences USA 107:11140-11144.

Koh, L. P., J. Miettinen, S. C. Liew, and J. Ghazoul. 2011. Remotely sensed evidence of tropical peatland conversion to oil palm. Proceedings of the National Academy of Sciences USA 108(12):5127-5132.

Kramer-Schadt, et al. 2013. The importance for correcting for sampling bias in MaxEnt distribution models. Diversity and Distributions 19(11):1366-1379.

Lambin, E. F., H. J. Geist, and E. Lepers. 2003. Dynamics of land-use and land-cover change in tropical regions. Annual Review of Environment and Resources 28:205-241.

Landis, J. R., and G. G. Koch. 1977. The measurement of observer agreement for categorical data. Biometrics 33:159174.

Langner, A., and F. Siegert. 2009. Spatiotemporal fire occurrence in Borneo over a period of 10 years. Global Change Biology 15:48-62.

Laterra, P., M. E. Orúea, and G. C. Boomana. 2012. Spatial complexity and ecosystem services in rural landscapes. Agriculture Ecosystems and Environment 154:56-67.

Lavorel, S., K. Grigulis, P. Lamarque, M. P. Colace, D. Garden, J. Girel, G. Pellet, and R. Douzet. 2011. Using plant functional traits to understand the landscape distribution of multiple ecosystem services. Journal of Ecology 99:135-147.

Law, E. A., B. A. Bryan, M. Torabi, S. A. Bekessy, C. A. McAlpine, and K. A. Wilson. In press. Measurement matters in managing landscape carbon. Ecosystem Services.

Law, E. A., S. Thomas, E. Meijaard, P. J. Dargusch, and K. A. Wilson. 2012. A modular framework for management of complexity in international forest-carbon policy. Nature Climate Change 2:155-160.

Maes, J., et al. 2013. Mapping and assessment of ecosystems and their services. An analytical framework for ecosystem assessments under action 5 of the EU Biodiversity Strategy to 2020. Publications office of the European Union, Luxembourg, Luxembourg.

Mallawaarachchi, T., and J. Quiggin. 2001. Modelling socially optimal land allocations for sugar cane growing in north Queensland: a linked mathematical programming and choice modelling study. Australian Journal of Agricultural and Resource Economics 45:383-409.

Margules, C., and S. Sarkar. 2007. Systematic conservation planning. Cambridge University Press, Cambridge, UK.

Medrilzam, and P. Dargusch. 2011. Definition of forest for REDD+: an unresolved issue. Annals of Tropical Research 33:19-30.

Meijaard, E. 1997. The importance of swamp forest for the conservation of orang utans (Pongo pygmaeus pygmaeus) in Kalimantan, Indonesia. Pages 243-254 in S. E. Page and J. O. Rieley, editors. Proceedings of the International Symposium on the Biodiversity, Environmental Importance and Sustainability of Tropical Peat and Peatlands. Samara Publishing, Cardigan, UK.

Meijaard, E., and V. Nijman. 2003. Primate hotspots on Borneo: predictive value for general biodiversity and the effects of taxonomy. Conservation Biology 17:725-732.

Miettinen, J., A. Hooijer, C. Shi, D. Tollenaar, R. Vernimmen, S. C. Liew, C. Malins, and S. E. Page. 2012. Extent of industrial plantations on Southeast Asian peatlands in 2010 with analysis of historical expansion and future projections. Global Change Biology Bioenergy 4:908-918.

Millennium Ecosystem Assessment. 2005. Ecosystems and human well-being: synthesis. Island Press, Washington, D.C., USA.

Morrogh-Bernard, H., S. Husson, S. E. Page, and J. O. Rieley. 2003. Population status of the Bornean orang-utan (Pongo pygmaeus) in the Sebangau peat swamp forest, Central Kalimantan, Indonesia. Biological Conservation 110:141152.

Murdiyarso, D., K. Hergoualc'h, and L. V. Verchot. 2010. Opportunities for reducing greenhouse gas emissions in tropical peatlands. Proceedings of the National Academy of Sciences USA 107:19655-19660.

Naidoo, R., A. Balmford, R. Costanza, B. Fisher, R. E. Green, B. Lehner, T. R. Malcolm, and T. H. Ricketts. 2008. Global mapping of ecosystem services and conservation priorities. Proceedings of the National Academy of Sciences USA 105:9495-9500.

Naidoo, R., and T. H. Ricketts. 2006. Mapping the economic costs and benefits of conservation. PLoS Biology 4:e360.

Nassauer, J., and P. Opdam. 2008. Design in science: extending the landscape ecology paradigm. Landscape Ecology 23:633644 .

Nelson, E., et al. 2009. Modeling multiple ecosystem services, biodiversity conservation, commodity production, and tradeoffs at landscape scales. Frontiers in Ecology and the Environment 7:4-11.

Obidzinski, K., R. Andriani, H. Komarudin, and A. Andrianto. 2012. Environmental and social impacts of oil palm plantations and their implications for biofuel production in Indonesia. Ecology and Society 17(1):Article 25.

Obidzinski, K., and M. Chaudhury. 2009. Transition to timber plantation based forestry in Indonesia: towards a feasible new policy. International Forestry Review 2:79-87.

OECD. 2005. Glossary of statistical terms. Organisation for Economic Co-operation and Development, Paris, France. http://stats.oecd.org/glossary/index.htm

O'Farrell, P., et al. 2010. Multi-functional landscapes in semi arid environments: implications for biodiversity and ecosystem services. Landscape Ecology 25:1231-1246.

Osorio, F., R. Vallejos, and F. Cuevas. 2012. SpatialPack: package for analysis of spatial data. $\mathrm{R}$ package version 0.2 . http://CRAN.R-project.org/package=SpatialPack

Page, S., et al. 2009. Restoration ecology of lowland tropical peatlands in Southeast Asia: current knowledge and future research directions. Ecosystems 12:888-905.

Page, S. E., F. Siegert, J. O. Rieley, H. D. V. Boehm, A. Jaya, and S. Limin. 2002. The amount of carbon released from peat and forest fires in Indonesia during 1997. Nature 420:61-65.

Paoli, G. D., P. L. Wells, E. Meijaard, M. J. Struebig, A. J. Marshall, K. Obidzinski, A. Tan, A. Rafiastanto, B. Yaap, and J. F. Slik. 2010. Biodiversity conservation in the REDD. Carbon Balance and Management 5:7.

PEACE. 2007. Indonesia and climate change: current status and policies. PT Pelangi Energi Abadi Citra Enviro, Jakarta, Indonesia.

Phillips, S. J. 2004. A maximum entropy approach to species distribution modeling. Pages 655-662 in R. Greiner and D. Schuurmans, editors. Proceedings of the 21st International Machine Learning Conference, ACM Press, New York, New York, USA.

Phillips, S. J., R. P. Anderson, and R. E. Schapire. 2006. Maximum entropy modeling of species geographic distributions. Ecological Modelling 190:231-259.

Posa, M. R. C. 2011. Peat swamp forest avifauna of Central Kalimantan, Indonesia: effects of habitat loss and degradation. Biological Conservation 144:2548-2556. 
Posa, M. R. C., L. S. Wijedasa, and R. T. Corlett. 2011. Biodiversity and conservation of tropical peat swamp forests. BioScience 61:49-57.

Posthumus, H., J. R. Rouquette, J. Morris, D. J. G. Cowing, and T. M. Hess. 2010. A framework for the assessment of ecosystem goods and services; a case study on lowland floodplains in England. Ecological Economics 69:1510-1523.

R Core Team. 2012. R: A language and environment for statistical computing. R Foundation for Statistical Computing, Vienna, Austria. http://www.R-project.org/

Raudsepp-Hearne, C., G. D. Peterson, and E. M. Bennett. 2010. Ecosystem service bundles for analyzing tradeoffs in diverse landscapes. Proceedings of the National Academy of Sciences USA 107:5242-5247.

Republic of Indonesia. 1990. President decree no. 32 year 1990: the management of protected areas. Issued July 1990. [In Indonesian.] http://bksdadiy.dephut.go.id/images/data/ PENATAAN KAW.LINDUNG.pdf

Republic of Indonesia. 2007. Presidential Instruction No. 2/ 2007: acceleration of rehabilitation and revitalisation of the peat land development area in Central Kalimantan. [In Indonesian.] http://www.presidenri.go.id/DokumenUU.php/ 400.pdf

Reyers, B., P. O'Farrell, J. Nel, and K. Wilson. 2012. Expanding the conservation toolbox: conservation planning of multifunctional landscapes. Landscape Ecology 27:11211134.

Ripley, B. 2012. tree: classification and regression trees. R package version 1.0-32. http://CRAN.R-project.org/package= tree

Rist, L., L. Feintrenie, and P. Levang. 2010. The livelihood impacts of oil palm: smallholders in Indonesia. Biodiversity and Conservation 19:1009-1024.

Rodriguez, J. P., T. D. Beard, Jr., E. M. Bennett, G. S. Cumming, S. J. Cork, J. Agard, A. P. Dobson, and G. D. Peterson. 2006. Trade-offs across space, time, and ecosystem services. Ecology and Society 11:Article 28.

Ruijs, A., A. Wossink, M. Kortelainen, R. Alkemade, and C. J. E. Schulp. 2013. Trade-off analysis of ecosystem services in Eastern Europe. Ecosystem Services 4:82-94.

Ruslandi, O. Venter, and F. E. Putz. 2011. Overestimating conservation costs in Southeast Asia. Frontiers in Ecology and the Environment 9:542-544.

Segan, D. B., E. T. Game, M. E. Watts, R. R. Stewart, and H. P. Possingham. 2011. An interoperable decision support tool for conservation planning. Environmental Modelling and Software 26:1434-1441.

Silvius, M., and N. Suryadiputra. 2004. Review of policies and practices in tropical peat swamp forest management in Indonesia. Water for Food and Ecosystems, Wetlands International, Wageningen, Netherlands.

Strassburg, B., et al. 2010. Global congruence of carbon storage and biodiversity in terrestrial ecosystems. Conservation Letters 3:98-105.

Thomas, S., P. Dargusch, S. Harrison, and J. Herbohn. 2010. Why are there so few afforestation and reforestation clean development mechanism projects? Land Use Policy 27:880887.
Turner, R. K., J. Paavola, P. Cooper, S. Farber, V. Jessamy, and S. Georgiou. 2003. Valuing nature: lessons learned and future research directions. Ecological Economics 46:493-510. van den Berg, J., and P. Widiadi. 2008. Technical report number 12: improving livelihoods in the Ex-Mega Rice Project Area in Central Kalimantan. In: Master plan for the rehabilitation and revitalisation of the Ex-Mega Rice Project Area in Central Kalimantan. Euroconsult Mott MacDonald, Deltares | Delft Hydraulics, DHV, Wageningen UR, WitteveenPBos, PT MLD, and PT INDEC. Palangka Raya, Central Kalimantan, Indonesia.

van der Meer, P., and B. F. Ibie. 2008. Technical report number 6: forestry in the Ex-Mega Rice Project Area in Central Kalimantan. In Master plan for the rehabilitation and revitalisation of the Ex-Mega Rice Project Area in Central Kalimantan. Euroconsult Mott MacDonald, Deltares | Delft Hydraulics, DHV, Wageningen UR, WitteveenPBos, PT MLD, and PT INDEC. Palangka Raya, Central Kalimantan, Indonesia.

Venter, O., W. Laurance, T. Iwamura, K. Wilson, R. Fuller, and H. Possingham. 2009a. Harnessing carbon payments to protect biodiversity. Science 326:1368.

Venter, O., E. Meijaard, H. Possingham, R. Dennis, D. Sheil, S. Wich, L. Hovani, and K. Wilson. 2009b. Carbon payments as a safeguard for threatened tropical mammals. Conservation Letters 2:123-129.

Venter, O., H. P. Possingham, L. Hovani, S. Dewi, B. Griscom, G. Paoli, P. Wells, and K. A. Wilson. 2012. Using systematic conservation planning to minimize REDD+ conflict with agriculture and logging in the tropics. Conservation Letters 6(2): $116-124$.

Wendland, K. J., M. Honzak, R. Portela, B. Vitale, S. Rubinoff, and J. Randrianarisoa. 2010. Targeting and implementing payments for ecosystem services: opportunities for bundling biodiversity conservation with carbon and water services in Madagascar. Ecological Economics 69:2093-2107.

Wich, S. A., et al. 2012. Understanding the impacts of land-use policies on a threatened species: is there a future for the Bornean orang-utan? PLoS One 7:e49142.

Willemen, L., L. Hein, M. E. F. van Mensvoort, and P. H. Verburg. 2010. Space for people, plants, and livestock? Quantifying interactions among multiple landscape functions in a Dutch rural region. Ecological Indicators 10:62-73.

Willemen, L., A. Veldkamp, P. H. Verburg, L. Hein, and R. Leemans. 2012. A multi-scale modelling approach for analysing landscape service dynamics. Journal of Environmental Management 100:86-95.

Willemen, L., P. H. Verburg, L. Hein, and M. E. F. van Mensvoort. 2008. Spatial characterization of landscape functions. Landscape and Urban Planning 88:34-43.

Wilson, K. A., et al. 2010. Conserving biodiversity in production landscapes. Ecological Applications 20:17211732.

Wise, M., K. Calvin, A. Thomson, L. Clarke, B. BondLamberty, R. Sands, S. J. Smith, A. Janetos, and J. Edmonds. 2009. Implications of limiting $\mathrm{CO}_{2}$ concentrations for land use and energy. Science 324:1183-1186.

Wosten, J. H. M., E. Clymans, S. E. Page, J. O. Rieley, and S. H. Limin. 2008. Peat-water interrelationships in a tropical peatland ecosystem in Southeast Asia. Catena 73:212-224.

\section{Supplemental Material}

\section{Ecological Archives}

Appendices A-F are available online: http://dx.doi.org/10.1890/13-2014.1.sm 